\title{
Systematic review about 10 interventions in dermatitis. A document from the Latin American Society of Allergy, Asthma, and Immunology
}

\section{Revisión sistemática sobre 10 intervenciones en dermatitis. Un documento de la Sociedad Latinoamericana de Alergia}

\section{Asma e Inmunología}

Jorge Sánchez, ${ }^{1}$ Mario Roberto Sánchez, ${ }^{2}$ Alejandra Macías-Weinmann, ${ }^{3}$ Bruno Barreto, ${ }^{4}$ Luis Felipe Ensina, ${ }^{5}$ Silvia Antonieta Uriarte-Obando, ${ }^{6}$ Raúl Lázaro Castro-Almarales, ${ }^{7}$ Romina Adorni, ${ }^{8}$ Milagros Lázaro, ${ }^{9}$ Ariel Callero-Viera, ${ }^{10}$ Iris Ale, ${ }^{11}$ Leidy Álvarez ${ }^{12}$

\begin{abstract}
The Latin American Society of Allergy, Asthma, and Immunology (SLAAI) conducted a systematic search in the Medline and LILACS' database in order to get articles linked to 10 current questions about dermatitis. The assessment of the quality of the evidence and the strength of the recommendations was made through the GRADE system. The completeness and transparency of the recommendations for this clinical guide were assessed with the AGREE Reports Verification Checklist. The final document was shared with physicians, allergists, dermatologists, and pediatricians, and with patients and academic institutions such as universities and medical scientific societies for external assessment. According to the review, clinical scales should be used to measure the severity of the dermatitis, and some interventions such as the use of probiotics may benefit the patient; nevertheless, more studies are required before this management option can be used in the everyday practice. Other interventions such as dietary restrictions and the use of antihistamines seem to be well-founded only in particular cases and they should not be a general recommendation for all patients. This practical guide presents recommendations for the treatment of atopic dermatitis; these recommendations can be helpful for medical staff, patients, and health systems.
\end{abstract}

Keywords: Allergy; Allergen; Atopy; Dermatitis; Eczema; Probiotics; Antihistamines; Dupilumab; Microbiota

How to cite this article: Sánchez J, Sánchez MR, Macías-Weinmann A, Barreto B, Ensina LF, Uriarte-Obando SA, et al. Systematic review about 10 interventions in dermatitis. A document from the Latin American Society of Allergy, Asthma, and Immunology. Rev Alerg Mex. 2019;66(4):426-455

ORCID

Jorge Sánchez, 0000-0001-6341-783X; Mario Roberto Sánchez, 0000-0003-2720-6810;

Alejandra Macías-Weinmann, 0000-0003-4007-2255; Bruno Barreto, 0000-0001-6892-0004;

Luis Felipe Ensina, 0000-0001-8652-3619; Silvia Antonieta Uriarte-Obando, 0000-0002-6132-3642;

Raúl Lázaro Castro-Almarales, 0000-0002-9344-473X; Romina Adorni, 0000-0003-2130-0005;

Milagros Lázaro, 0000-0002-3124-0854; Ariel Callero-Viera, 0000-0002-8964-8262;

Iris Ale, 0000-0001-8111-2140; Leidy Álvarez, 0000-0003-2893-1109 


\section{Resumen}

La Sociedad Latinoamericana de Asma, Alergia e Inmunología realizó una búsqueda sistemática en la base de datos de Medline y LILACS para obtener artículos relacionados con 10 preguntas actuales sobre dermatitis. La evaluación de la calidad de la evidencia y la fuerza de las recomendaciones se realizaron a través del sistema GRADE. La integridad y la transparencia de las recomendaciones se evaluaron con la lista de verificación de informes AGREE. El documento final se compartió con médicos, alergólogos, dermatólogos y pediatras, pacientes e instituciones académicas, como universidades y sociedades médicas científicas, para su evaluación externa. Conforme a la revisión, se debe usar escalas clínicas para evaluar la gravedad de la dermatitis; algunas intervenciones como el uso de probióticos pueden beneficiar al paciente, sin embargo, se requieren más estudios antes de utilizarlas en la práctica diaria. La restricción de la dieta y el uso de antihistamínicos parecen tener fundamento solo en casos particulares y no deben indicarse a todos los pacientes. Esta guía práctica presenta recomendaciones para el tratamiento de la dermatitis atópica que pueden ser útiles para el personal médico, los pacientes y los sistemas de salud.

Palabras clave: Alergia; Alérgeno; Atopia; Dermatitis; Eccema; Probióticos; Antihistamínicos; Dupilumab; Microbiota

${ }^{1}$ Universidad de Antioquia, Grupo de Alergia Clínica y Experimental, Medellín, Colombia

2Unidad Médica San Ángel, Zapopoan, Jalisco, México

${ }^{3}$ Universidad Autónoma de Nuevo León, Hospital Universitario Dr. José Eleuterio González, Monterrey, Nuevo León, México

${ }^{4}$ Centro Universitário do Estado do Para, São Paulo, Brasil

${ }^{5}$ Universidade Federal de São Paulo, São Paulo, Brasil

${ }^{6}$ Hospital Cayetano Heredia, Servicio de Inmuno Reumatología,

Lima, Perú

${ }^{7}$ Centro Nacional de Biopreparados, Grupo de Ensayos Clínicos, Bejucal, Cuba

${ }^{8}$ Universidad Nacional de La Plata, Hospital Profesional Dr. Rodolfo

Rossi, La Plata, Argentina
${ }^{9}$ Hospital Universitario de Salamanca, Servicio de Alergia,

Salamanca, España

${ }^{10}$ Hospital Universitario Nuestra Señora de Candelaria, Servicio de Alergia, Tenerife, España

${ }^{11}$ Universidad de la República de Uruguay, Facultad de Medicina, Montevideo, Uruguay

${ }^{12}$ Universidad de Antioquia, Medellín, Antioquia, Colombia

Correspondence: Jorge Sánchez. jorgem.sanchez@udea.edu.co

Received: 2019-065-13

Accepted: 2019-10-19

DOI: $10.29262 /$ ram.v66i4.636

\section{Abbreviations and acronyms}

$A D$, atopic dermatitis

$A Z A$, azathioprine

CSA, cyclosporine A

FDA, Food and Drugs Administration

GRADE, Grading of Recommendations, Assessment,

Development, and Evaluation

IL, interleukin
MTX, methotrexate

$\mathrm{RCT}$, randomized controlled trial

SCORAD, Severity Scoring Atopic Dermatitis

SCSs, systemic corticosteroids

SLAAI, Sociedad Latinoamericana de Asma, Alergia e Inmunología

WAO, World Allergy Organization

\section{Background}

Atopic dermatitis (AD) affects a large portion of the population, particularly children under 5 years. ${ }^{1,2,3,4}$ It usually precedes the development of other allergic diseases such as food allergy, asthma, rhinitis, and/ or conjunctivitis, therefore, it is considered as an important risk factor for these diseases. ${ }^{5,6}$

$\mathrm{AD}$ has a great impact on the quality of life of patients. The frequency of physiological or psychiatric problems in patients with moderate to severe 
dermatitis is higher than those in patients with diabetes mellitus. $^{7}$ The economic cost of skin hydration, physician visits, and drug treatment has increased in the last years. ${ }^{8,9,10}$ Therefore, the evaluation and management of AD should be comprehensive and must include all the stakeholders: patients, relatives, and health care systems.

Although there are excellent guidelines offering an appropriate approach to manage this disease, ${ }^{11,12}$ transparent evidence-based guidelines following the GRADE (Grading of Recommendations, Assessment, Development, and Evaluation) approach ${ }^{13}$ are needed. ${ }^{14}$ Since each patient must receive personalized treatment, the recommendations presented here may not be appropriate for all patients, nevertheless, they offer a kickoff for disease management based on current scientific evidence.

\section{Methods}

- Update objectives: to evaluate some commonly used interventions in dermatitis and new practical interventions.

- Target population: patients with AD regardless their age, but it is focused on under- 6 children because they are the population with the highest AD incidence. ${ }^{15}$

- Implementation place: these recommendations are to be implanted on outpatient clinical management.

- Target users: general practitioners, family doctors, dermatologists, allergists, and pediatricians.

- Clinical aspects covered: evaluation of topical and systemic dermatitis management interventions. Prevention and acute management. Outpatient management.

- Clinical aspects not covered: management in hospitalization and/or emergencies.

\section{Definitions}

According to the recommendation of the WAO (World Allergy Organization), ${ }^{16}$ it is better to use the term "eczema" than "dermatitis", while confirmatory immunological studies are done; also, WAO recommends limiting the use of the term "atopic eczema" when a mediation IgE is demonstrated in the pathophysiology of the disease, and "non-atopic eczema" when it is discarded. In many countries, the term "dermatitis" is used as an equivalent to "eczema", so, in this guideline and in the bibliographic search we use both. ${ }^{17,18,19}$

\section{Staff conformation}

Since the first revision of the Dermatitis-SLAAI (Sociedad Latinoamericana de Asma, Alergia e Inmunología) Guidelines in $2015,{ }^{20}$ new evidence has accumulated about some interventions in AD.

For this update, a stakeholder group with allergists, dermatologists, pediatricians, epidemiologists, and immunologists, developed the review protocol and made an open invitation to SLAAI members to participate. ${ }^{21}$ Subsequently, those members who correctly performed the protocol tasks and writing the guide were included in the staff.

\section{Protocol to the guide update}

This guideline update was focused on new information about some practical interventions in dermatitis. Characteristics of the epidemiology, classification, and pathogenesis of the disease are discussed in detail in the 2015 Consensus. ${ }^{20}$ ARIA (Allergic Rhinitis and its Impact on Asthma) report protocol was used as a model ${ }^{22}$ and the update protocol was based on PRISMA recommendations (see supplementary material). ${ }^{23}$

By using the Delphi process, ${ }^{24}$ the panel staff reached an agreement on the topics that required an update and on new topics that deserved to be included, and performed a systematic review of the literature to identify and summarize the evidence for each one of them (see supplementary material). Each topic is presented as a clinical question, and the answer to each question includes a conclusion with the strength of the recommendation according to the GRADE system. ${ }^{14}$ The AGREE Reporting Checklist was used to evaluate the completeness and transparency of the guideline recommendations.

For external validation and to assess the clarity of the concepts and their applicability, the manuscript was presented to allergists, dermatologists, general physicians from academic and external scientific institutions, and groups of patients. External recommendations were then discussed again by the staff and included in the manuscript.

\section{Questions and outcomes of interest}

The guideline panel deemed the following outcomes to be important to patients: cutaneous symptoms like pruritus and eczema, quality of life, work/school performance, and serious adverse effects. In general, these variables were considered critical for the 
decisions to be made, regarding the answer to each question. The questions chosen were:

1. How should we classify atopic dermatitis in clinical practice?

2. Can atopic dermatitis be prevented?

3. Can we predict the duration of atopic dermatitis?

4. Does the cutaneous microbiota influence the control of atopic dermatitis?

5. Is the use of probiotics in atopic dermatitis useful?

6. Can restriction diet help as a treatment of atopic dermatitis?

7. Are non-pharmacological interventions useful in the treatment of dermatitis?

8. Do antihistamines help in the treatment of atopic dermatitis?

9. When and which immunomodulator should be used in atopic dermatitis?

10. What new pharmacological treatments are available for atopic dermatitis?

\section{Bibliographic search and evidence review}

We systematically searched articles from December 2000 to December 2018 from the Medline and LILACs electronic databases. Titles and abstracts, and subsequently full-text articles were screened in duplicate to assess eligibility. Articles in English, Spanish and Portuguese were reviewed.

Studies were included if they provided empirical data related to the panel staff questions (clinical trials, cohort studies, case-control studies). We excluded narrative reviews and case reports. We shared the bibliography collected among the team members; in case any staff member considered it was necessary to include an additional reference, this was discussed.

\section{Clinical recommendations}

We prepared evidence summaries for each question according to the GRADE approach. ${ }^{14,25}$ The certainty of the evidence was categorized into four levels: strong, moderate, low, and very low. Specific criteria for evidence classification are presented in figure 1.

For each question, we summarized all information including a concise description of desirable and undesirable health effects. ${ }^{26,27}$ The answer to each question was reviewed by the panel staff, who provided feedback by means of electronic communications. The answers were modified accordingly when it was necessary. Recommendations and their strength were decided by consensus.

\section{Results}

\section{Limitations from the systematic review}

The protocol for this systematic review was not previously registered in any database, which limits the reproducibility of the results. However, since in the guide we considered the patients' opinions and the reality of the clinical practice in different countries, these variables, that influenced the recommendation, could not be reproduced only with the bibliographic search. In supplementary material 1 and 2, an approach of the search carried out for each question is presented. However, a standardized evaluation to avoid the risk of bias was not used.

\section{Limitations from articles}

There is a considerable heterogeneity among the studies, patients' characteristics, evaluation of clinical control, and the safety of each intervention. Additionally, many studies indicated the response to treatment without clarifying the doses of the drug, the treatment length, measurement of treatment efficacy, the speed of the effect, and/or follow-up period. We provide the rationale for the recommendations and the consideration of some factors that influenced the recommendations.

\section{How should we classify atopic dermatitis in clinical practice?}

Recommendation. Severity classification is available to all physicians and it is useful to define interventions (high, 1a). Atopy-based classification (yes/no) seems to be useful for the prognostic of duration in children (moderate 1a).

Explanation. AD can be classified in several ways. ${ }^{20}$ Some classification proposals according to endotypes have been done, ${ }^{28,29}$ but their utility in clinical practice is unclear. The presence or not of atopy seems to be associated with the patient's clinical characteristics and the probability of remission or not, thus, the classification of allergic or non-allergic eczema according to the skin prick test result or IgE serum can be useful in the clinical practice. The classification of the severity is established with different scoring scales, such as: Severity Scoring 


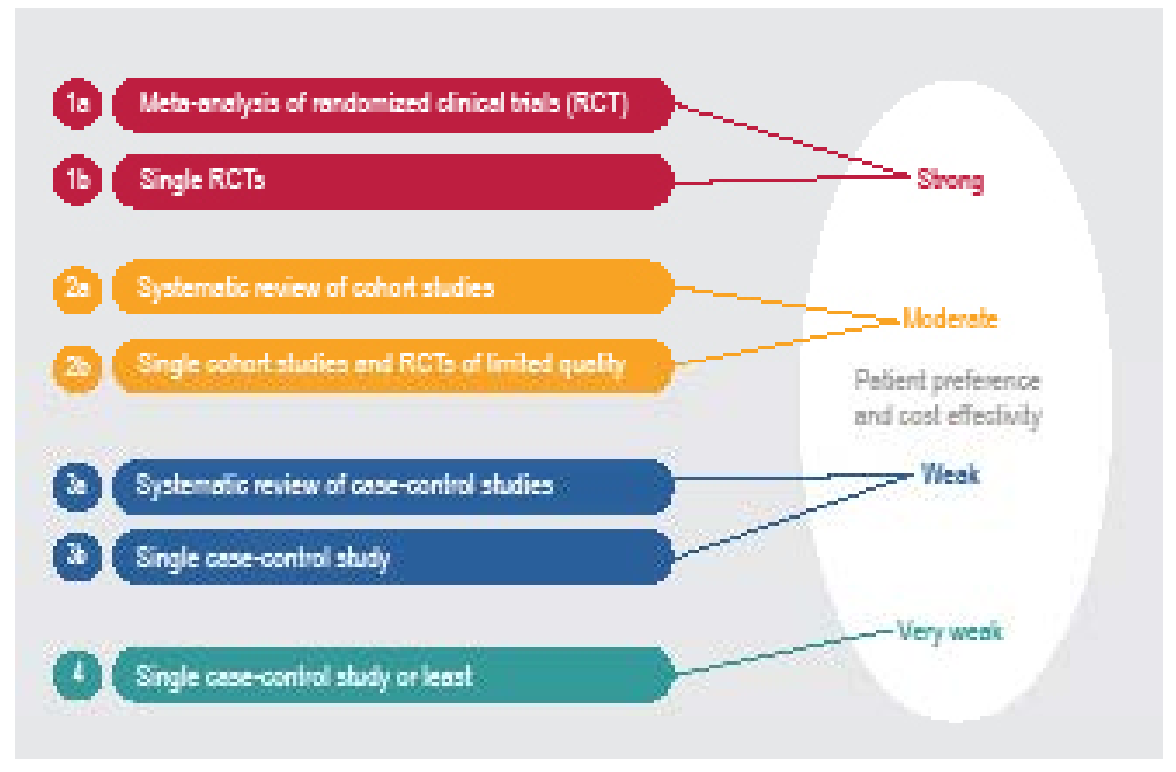

Figure 1. Classification of the evidence. The recommendation was classified based on the grade of evidence and the interpretation of the committee. We considered patient preferences and cost effectivity.
Atopic Dermatitis (SCORAD) and Eczema Area and Severity Index. These scores are defined according to three parameters: extension of the disease and type of injury; some scales also include pruritus and sleep disturbance as perceived by the patient. We recommend the use of these or any other validated clinical scale since they allow physicians to classify the severity of the patient, the degree of affectation and allow the decision making regarding the most appropriate medical intervention.

\section{Can atopic dermatitis be prevented?}

Recommendation. Primary prevention: early skin hydration (first six months of life) seems to decrease the risk of dermatitis (strong 1b). Secondary prevention: skin hydration and inflammation control improve the clinical control of dermatitis, and some evidence suggests that these interventions could modify the severity of eczema (moderate $2 b$ ).

Explanation. Primary prevention: the increase of IgA levels with breast milk ${ }^{30}$ and the use of milk hydrolyzed formulas in high-risk infants reduced the cumulative prevalence of eczema. ${ }^{31}$ Although these results are supported by some studies, other research studies do not reproduce these results, so their implementation cannot be widely recommended.

Two multicenter studies demonstrated that the daily use of emollients, with application on all the skin, significantly reduced the cumulative incidence of AD in children at 12 and 36 months, which corresponded to a relative risk reduction, between $30 \%$ and $50 \% .^{32,33}$ It is necessary to evaluate the cost-effectiveness of this intervention. ${ }^{34}$

Secondary prevention. The daily use of emollients in patients with mild-moderate disease prevents and delays exacerbations, as well as decreases the use of topical steroids and prolongs eczema-free time. ${ }^{35,36,37}$ Although there is controversial evidence, ${ }^{38}$ it seems that vitamin D supplementation during the winter season improves AD related to winter. ${ }^{39,40}$

\section{Can we predict the duration of atopic dermatitis?}

Recommendation. Maternal eczema, onset after two years old, severe onset, are associated with long duration of dermatitis periods (over 14 years old) (moderate $2 \mathrm{a}$ ). Nevertheless, no single factor is enough to predict the duration of the disease (strong $2 \mathrm{~b}$ ). The creation of a prognostic model evaluating the magnitude of each individual factor could be useful. ${ }^{41}$

Explanation. Most childhood dermatitis remitted before puberty, nevertheless, from $1 \%$ to $25 \%$ of patients persist with symptoms even in adulthood. ${ }^{20,41}$ Findings from 14 systematic reviews published before 2016 observed that persistent atopic dermatitis is associated with more severe disease at the time of diagnosis, onset after the age of two years and being a female. ${ }^{42}$ A systematic review in- 
cluding 45 studies was considered and found that a later onset increased persistence. ${ }^{43}$ Some genetic factors have been associated with persistent dermatitis, but these factors are not easy to use in clinical practice. $^{44}$

Some studies suggest that children with atopy from house dust mites or foods before their first year should be considered at risk of AD persistence, ${ }^{45,46}$ although it is not clear if atopy is a consequence of greater severity, it could be used as a duration predictor.

\section{Does the cutaneous microbiota influence the control of atopic dermatitis?}

Recommendation. The cutaneous microbiota influences the control of AD (strong 1b), however, heterogeneity in intervention strategies on bacterial overgrowth (topic or systemic antibiotics), makes comparative evaluations and the power of evidence difficult to extend and evaluate (moderate 2a).

Explanation. Microbial colonization of skin begins, more effectively, after birth and depends, in part, on the type of delivery; cesarean delivery children have a cutaneous microbiota profile that resembles maternal skin, while cutaneous microbiota of vaginal delivery children has a more diversified profile, similar to the maternal vaginal scenario. ${ }^{47}$ During puberty, new changes occur in skin microbiota. ${ }^{48}$ There are several mechanisms by which changes in microbial skin diversity (dysbiosis) affect the development of atopic dermatitis; the production, by these dysbiosis bacteria, of several enzymes, such as: proteases (which induce corneocyte desquamation); lipases (which break down lipids of skin barrier); ceramidases (which break down the ceramides present in the barrier structure). ${ }^{49,50}$ This bacterial overgrowth, with subsequent biofilm formation and mainly related to the pathogenic strains of Staphylococcus aureus (methicillin-resistant Staphylococcus aureus), would be directly related to changes in the cutaneous barrier. ${ }^{51,52,53}$

Cutaneous microbiota is associated with dermatitis severity, but it is less clear its effect in the pathogenesis; antibiotic interventions are also expected to be able to improve the dermatitis symptom scores. However, a systematic review, ${ }^{54}$ in 21 studies with different interventions (oral antibiotics, antibacterial soaps, topical steroids/antibiotics/antifungal, baths with antibacterial solutions) did not show differences statistically significant.
5. Is the use of probiotics in atopic dermatitis useful?

Recommendation. There is a potential effect of the use of probiotics in the prevention of atopic dermatitis (moderate 3a); however, methodological limitations, a wide variety of strains and the dosage schemes, lead to discordant and contradictory results and their routine use is not recommended.

Explanation. Probiotics could help dermatitis through restoration in the function of the intestinal barrier, degrading food antigens, regulating the Th1 and Th2 response, regulating the composition and activity of the intestinal microbiota and stimulating the production of IgA. ${ }^{55}$ The WAO in a systematic review indicates that is likely net benefit from using probiotics the primary prevention of eczema. ${ }^{56}$ The use of Lactobacillus rhamnosus, Lactobacillus salivarius, Bifidobacterium lactis and others, in several small studies has shown relief of symptoms, which results in an improvement of SCORAD, ${ }^{57,58}$ being more effective during the first two years of life.

Although probiotics are safe and are used as a reasonable option of dermatitis preventive treatment in under-6-month children or high-risk pregnant women, their impact on active treatment appears to be reduced. ${ }^{59,60}$

However, in order to apply this recommendation, solving several practical questions that currently do not have an answer is necessary, for instance: Does the type of microbiota affect the impact of probiotics? What dosage? For how long? What strains should be used?. ${ }^{61}$ The lack of control of these variables in the different clinical trials limits the ability to implement this intervention.

\section{Can restriction diet help as a treatment of atopic dermatitis?}

Recommendation. In patients with an objective demonstration of exacerbation of dermatitis by a food, dietary restriction is indicated (moderate $3 a$ ). Atopy to food allergens is not enough to initiate a dietary restriction (strong 1a).

Explanation. Frequently, patients associate food consumption with the onset or worsening of their disease. ${ }^{62,63,64}$ The sensitization to foods in children with $\mathrm{AD}$ is very prevalent, being the majority of cases asymptomatic (without clinical relevance) ${ }^{65,66}$ The subgroup of moderate to severe AD have a higher risk of sensitization to food allergens and this is translated 
into a high risk of true food allergy. ${ }^{65,67,68}$ The clinical history, along with an allergology evaluation, can help to identify suspect foods, but it is necessary to verify with restriction diets for 3 to 4 weeks or controlled oral challenges.

The avoidance of foods previously tolerated or never ingested due to a positive skin test without clinical confirmation of hypersensitivity reactions, is associated with an increased risk of severe reactions, after their reintroduction into the regular diet. ${ }^{69,70,71,72}$ Therefore, the avoidance of food should only occur in cases of $\mathrm{AD}$ with clinical impact confirmation. ${ }^{73}$ In cases in which negative results in oral challenges or food restrictions did not improve $\mathrm{AD}$, foods must be reintroduced. ${ }^{74}$

\section{Are non-pharmacological interventions useful} in the treatment of dermatitis?

Recommendation. The hydration of the skin is a non-pharmacological intervention with adequate evidence for the treatment and prevention of eczema exacerbation in dermatitis (moderate 2a). Although the evidence is weak and the magnitude of this measure is not known, we recommend the use of hypochlorite, loose and preferably cotton-made clothing in patients with $\mathrm{AD}$ (low 3a-4). We discourage the use of products with perfume or clothing that may increase sweating (low $3 b$ ).

Explanation. The treatment of $\mathrm{AD}$ is a challenge because it is a chronic disease, which occurs with periods of outbreak and remission. The therapeutic approach of dermatitis includes two aspects: the management of active eczema and the prevention of new exacerbations.

The emollient preparation should be chosen according to the skin dryness degree, the areas of application, and the patient's acceptance. ${ }^{75,76}$ Using tight or rough clothes, personal care products with alcohol or perfume, exposing oneself to heat or carrying out activities inducing heavy sweating, among others, should be avoided as far as possible. ${ }^{77,78}$ Some recommendations with low evidence but cost-effective are usually done: baths should be tempered and brief, no more than five minutes. Skin hygiene and cleaning should be smooth, scabs should be removed; avoid perfumes. Using hypochlorite during bath could reduce colonization of some bacteria. ${ }^{79,80,81}$ Using comfortable, loose and preferably cotton-made clothing seems to prevent skin exacerbation.
8. Do antihistamines help in the treatment of atopic dermatitis?

Recommendation. Some studies support the use of second-generation antihistamines to decrease pruritus in dermatitis (low 4). However, due to the lack of high-level evidence, we cannot make a recommendation in favor of or against the use of H1-antihistamines in the treatment of dermatitis-associated pruritus.

Explanation. Pruritus is usually the most distressing feature of AD. ${ }^{82}$ Histamine is one of the multiple mediators of itching in dermatitis. However, it is not clear if it has a key role. ${ }^{83}$ There are no large, randomized, double-blind, and placebo-controlled studies with precise endpoints on the efficacy of antihistamines in AD. Antihistamines (especially first generation) have been used in dermatitis to reduce scratching, however, these drugs, in most of the studies, are not more effective than placebo. ${ }^{84,85,86,87}$ Nevertheless, some studies, especially those with second-generation antihistamines, suggest a possible positive effect in pruritus and repair of the cutaneous tissue; $; 8,89,90,91$ these effects increased with a topical steroid. ${ }^{92}$

First generation sedating antihistamines have been used in dermatitis to promote sleep ${ }^{84,85}$ but sedating antihistamines reduce the rapid-eye-movement (REM)-sleep, affecting the quality of sleep and directly interfering with work efficiency in adults and learning skills in children. ${ }^{93}$

\section{When and what immunomodulator should be used in atopic dermatitis?}

Recommendation. The decision to start systemic therapy should be based on the severity of the symptoms, but also on the impact on the patient's quality of life, as well as on the consideration of the risks and benefits of systemic therapies for each individual patient (strong $1 \mathrm{~b}$ ). Many randomized controlled trials (RCTs) with immunomodulator interventions for dermatitis have not used standardized efficacy outcome measures, which makes interpretation of results difficult. In addition, comparative studies between the existent systemic treatments in dermatitis are rare.

Explanation. Most patients with $\mathrm{AD}$ respond satisfactorily to conventional topical management. However, $10 \%$ to $50 \%$ of patients may not achieve adequate disease control with these regimens and 
require systemic immunomodulatory/immunosuppressive therapies. Before considering a systemic therapy, it should be determined whether the failure of conventional therapies is due to the severity of the disease, comorbidities, or lack of adherence to the treatment. The action mechanism of each one of these interventions is explained in detail in the previous dermatitis-SLAAI guideline. ${ }^{20}$ In table 1 , we present some details of each one of some of these therapies. It is important to note that most of these therapies are not approved by the FDA or EMA for dermatitis.

- Dupilumab. It was approved in early 2017 for moderate-to-severe adult dermatitis. ${ }^{94,95}$ Dupilumab is a fully human monoclonal antibody that blocks the alpha subunit of the receptor interleukin (IL) 4 and IL-13. The blockade by dupilumab of these key drivers of type 2 help- er T-cell (Th2)-mediated inflammation help in the treatment of AD. Patients treated with dupilumab had marked and rapid improvement in all the evaluated measures of AD disease activity; Dupilumab also reduces the need for systemic steroids (NCT01259323, NCT01385657, NCT01639040, and NCT01548404.). ${ }^{95,96,97,98}$

- Phototherapy or photochemotherapy. It is one of the alternatives with the highest number of articles and some RCT supporting its effectiveness. However, the need of attendance to the center of execution between 2 to 4 times per week limits its access and use. ${ }^{99,100,101,102}$ Different forms of light therapy are available, and have proved efficacy: narrowband (NB)-UVB, broadband (BB)UVB, UVA, UVA1, cold-light UVA1, UVA and UVB (UVAB), full-spectrum light (including UVA, infrared and visible light), psoralen plus UVA, and other forms of phototherapy. One of

\begin{tabular}{|c|c|c|c|c|}
\hline $\begin{array}{l}\text { Systemic drug } \\
\text { intervention }\end{array}$ & Doses & Do not use in...* & $\begin{array}{l}\text { Efficacy- } \\
\text { effectivity** }\end{array}$ & $\begin{array}{c}\text { GRADE } \\
\text { recommendations }\end{array}$ \\
\hline Dupilumab & & $\begin{array}{l}\text { Serious eosinophilic } \\
\text { conditions }\end{array}$ & $50 \%-70 \%$ & Strong $1 \mathrm{a}$ \\
\hline Phototherapy & $40-120$ sessions & $\begin{array}{l}\text { Do not use in pregnancy } \\
\text { and children under } \\
6 \text {-year-old }\end{array}$ & $40 \%-70 \%$ & Moderate $2 b$ \\
\hline Cyclosporine A & $2.5-5 \mathrm{mg} / \mathrm{kg} / \mathrm{day}$ & Renal failure, pregnancy & $\begin{array}{c}30 \%-90 \% \text { after } \\
4 \text { months }\end{array}$ & Moderate $2 b$ \\
\hline Methotrexate & $\begin{array}{c}5-25 \text { mg once a week } \\
\text { (the use of MTX must be } \\
\text { complemented with folic } \\
\text { acid) }\end{array}$ & $\begin{array}{l}\text { Pregnancy, breastfeeding, } \\
\text { liver dysfunction }\end{array}$ & $30 \%-80 \%$ & Moderate $2 b$ \\
\hline Azathioprine & $1-2.5 \mathrm{mg} / \mathrm{kg} / \mathrm{day}$ & $\begin{array}{l}\text { Pregnancy, } \\
\text { mielosupression }\end{array}$ & $30 \%-70 \%$ & Moderate $2 b$ \\
\hline Mycophenolate (oral) & $1-3 \mathrm{~g} /$ day & Pregnancy, breastfeeding, & $20 \%-80 \%$ & Weak 3b \\
\hline Omalizumab & $\begin{array}{l}150 \mathrm{mg} / 4 \text { weeks to } \\
450 / 2 \text { weeks }\end{array}$ & $\begin{array}{l}\text { Patients without IgE } \\
\text { demonstration }\end{array}$ & $30 \%-50 \%$ & $\begin{array}{l}\text { Weak } 4 \text {, expert } \\
\text { opinion based in } \\
\text { case reports }\end{array}$ \\
\hline \multicolumn{5}{|c|}{$\begin{array}{l}\text { The selection of the systemic drug for dermatitis, more than a selection step by step, should be based in individual safety profile, availability and } \\
\text { access. The use of immunosuppressants can facilitate the onset of respiratory or skin infections. } \\
\text { *These medications may have other contraindications, the most frequently described are presented in the table. } \\
\text { **Different scales have been used to evaluated efficacy-effectivity, we present the effect size in percent as standard unit. The safety and efficacy } \\
\text { of dupilumab in children have not been established. }\end{array}$} \\
\hline
\end{tabular}


the principal limitations for phototherapy is the requirement to attend several times per week for its application. However, some new home-applied modalities are being developed. ${ }^{103}$

- Systemic corticosteroids (SCSs). They are not recommended as a control intervention for the treatment of dermatitis. Their use should be limited to very short terms (up to 1 week) during acute flares in need of immediate relief and as a transition to steroid-sparing therapies because of their adverse-effect potential. ${ }^{104,105,106}$

- Cyclosporine A (CSA). It is an approved drug for severe dermatitis in some countries and numerous studies showed improvement of the skin symptoms by at least $50 \%$ after six to eight weeks of therapy. ${ }^{107,108,109,110,111}$ Once the drug is stopped the symptoms reappear quickly, eventually reaching pretreatment values approximately after 8 weeks from the end of treatment. ${ }^{109,110,111}$ CSA has been shown to be effective and relatively safe in adults who received up to 1 year of continuous treatment, ${ }^{112,113,114,115,116}$ but some of these studies had high dropout rates. ${ }^{116}$ The staff recommended choosing the regimen on an individual basis; it could be reasonable to start with a dose of $2.5 \mathrm{mg} / \mathrm{kg} / \mathrm{day},{ }^{114,117}$ unless a rapid improvement is considered necessary, when a dose of up to $5 \mathrm{mg} / \mathrm{kg} /$ day may be used. ${ }^{116,118,119}$

- Methotrexate (MTX). Patients receiving MTX should be monitored for hepatic and pulmonary toxicity, and myelosuppression. ${ }^{120}$ Different studies have shown good efficacy for MTX. ${ }^{121,122}$ MTX has some advantages and disadvantages compared to CSA but it seems to have a similar effectivity; ${ }^{122,123,124}$ The onset of control seems to be faster with ciclosporin, but relapse after stopping the medication seems to be less frequent with MTX

- Azathioprine (AZA). Efficacy of AZA (2.5 mg/ $\mathrm{kg} /$ day) was tested in some RCT, especially in adults, ${ }^{107,125}$ with efficacy (30 to $70 \%$ ) in the severity of eczema and skin pruritus. In an RCT comparing MTX (10-22.5 mg/week) with AZA $(1.5-2.5 \mathrm{mg} / \mathrm{kg} /$ day $)$, at week 12 , no statistically significant differences were found in the clinical impact (MTX SCORAD of $42 \%$ (standard deviation [SD], $18 \%$ ) vs AZA $39 \%$ [SD, 25\%]), ${ }^{126}$ but abnormalities in blood count (mostly lymphocytopenia) were statistically and significant- ly more frequent in the AZA group $(\mathrm{p}=0.002)$.

- Mycophenolate (MMF). Some case reports or uncontrolled clinical trial data from adults indicate that MMF could be effective in dermatitis. ${ }^{127,128,129,130,131}$ In an observer-blinded randomized controlled trial in 55 patients, a lower dose CSA ( $3 \mathrm{mg} / \mathrm{kg} / \mathrm{d}$ ) was found to be equally effective to oral MMF (EC-MPS, $1440 \mathrm{mg} / \mathrm{d}$ ) as a maintenance therapy for severe dermatitis during a maintenance phase of 30 weeks and a 12-week follow-up period. ${ }^{112}$ The MMF group had a slower onset of action with $29 \%$ of the MMF patients requiring short courses of systemic glucocorticoids compared to none in the CSA group. ${ }^{132}$

Therapies like omalizumab, interferon gamma, and others, have been used in atopic dermatitis and may be useful for some patients but there are only case reports and case series supporting this recommendation. Some clinical trials are being conducted with omalizumab, but no results have been reported (Clinicaltrials.gov NCT01678092, NCT01179529).

10. What new pharmacological treatments are available for dermatitis?

Recommendation. Dupilumab is recommended in severe AD (strong 1a). Crisaborole is recommended in mild and moderate $\mathrm{AD}$, but a safety-efficacy comparison to other topical interventions is needed (strong 1a).

From the dermatitis-SLAAI guideline in 2015 to these days, two molecules were released to the market and approved by the Food and Drugs Administration (FDA): crisaborole, a topical phosphodiesterase 4 (PDE4) inhibitor, became available in late 2016 in the United States and Europe for mild-to-moderate dermatitis. It can be used topically. Clinical trials have demonstrated its efficacy in treating patients with mild to moderate atopic dermatitis (children $>2$ years) (AD-301: NCT02118766; AD-302: NCT02118792). ${ }^{133,134}$ The potency of crisaborole seems to be equivalent to the one of a moderate-potency steroid, but the frequency of adverse effects seems to be lower; as of now, there is no evidence of atrophy, telangiectasia, or hypopigmentation, resulting from its use. ${ }^{135}$ However, there are few equivalence or superiority studies comparing this molecule to topical steroids, therefore, at the moment, crisab- 
orole is recommended at the same level as the use of steroids or calcineurin inhibitors.

Dupilumab has been shown to be effective in adult patients refractory to topical steroids and also in patients who did not respond to CSA. ${ }^{136}$ Among the adverse effects that have been described are the increase of eosinophils in the blood (without apparent clinical impact, but it requires more studies) and a high frequency of conjunctivitis. ${ }^{137}$ The high cost of dupilumab and the lack of studies in children are the main limitations for its use.

\section{Conclusions}

For this update, we covered a small number of topics. However, these were systematically reviewed. Many interventions have been proven in patients with dermatitis, but due to the lack of studies with an adequate design, most of these interventions have a weak or moderate recommendation. Further studies are needed in order to predict the duration and sever- ity of the disease, as well as which interventions are the most appropriate for each patient.

\section{Funding}

This article was supported by the Group of Clinical and Experimental Allergy, from the Clinic IPS Universitaria of the University of Antioquia (Medellín, Colombia).

\section{Acknowledgment}

Special thanks to the scientific societies that participated as external reviewers of the guide: Mauricio Sarrazola and Eizabeth García (Asociación Colombiana de Alergia Asma e Inmunología); Mirta Álvarez Castelló, and Olaine Gray (Sociedad Cubana de Alergia, Asma e Inmunología Clínica); Natalia Hernández (Asociación Colombiana de Dermatología); Dirceu Solé (Associação Brasileira de Alergia e Imunologia); and Diana Gavazza (Academia Colombiana de Pediatría y Puericultura).

\section{References}

1. Odhiambo JA, Williams HC, Clayton TO, Robertson CF, Asher MI, ISAAC Phase Three Study Group. Global variations in prevalence of eczema symptoms in children from ISAAC Phase Three. J Allergy Clin Immunol. 2009;124(6):1251-1258. DOI: 10.1016/j.jaci.2009.10.009

2. Grize L, Gassner M, Wüthrich B, Bringolf-Isler B, Takken-Sahli K, Sennhauser FH, et al. Trends in prevalence of asthma, allergic rhinitis and atopic dermatitis in 5-7-year old Swiss children from 1992 to 2001. Allergy. 2006;61(5):556-562. DOI: 10.1111/j.1398-9995.2006.01030.x

3. Weber AS, Haidinger G. The prevalence of atopic dermatitis in children is influenced by their parents' education: results of two cross-sectional studies conducted in Upper Austria. Pediatr Allergy Immunol. 2010;21(7):1028-1035. DOI: 10.1111/j.1399-3038.2010.01030.x

4. Solé D, Mallol J, Wandalsen GF, Aguirre V, Latin American ISAAC Phase 3 Study Group. Prevalence of symptoms of eczema in Latin America: results of the International Study of Asthma and Allergies in Childhood (ISAAC) Phase 3. J Investig Allergol Clin Immunol. 2010;20(4):311-323. Available at: http:// www.jiaci.org/issues/vol20issue4/6.pdf

5. Barnetson RS, Rogers M. Childhood atopic eczema. BMJ. 2002;324(7350):1376-1379. DOI: 10.1136/ bmj.324.7350.1376

6. Gustafsson D, Sjöberg O, Foucard T. Development of allergies and asthma in infants and young children with atopic dermatitis: a prospective follow-up to 7 years of age. Allergy. 2000;55(3):240-245. DOI: 10.1034/j.1398-9995.2000.00391.x

7. Kemp AS. Cost of illness of atopic dermatitis in children: a societal perspective. Pharmacoeconomics. 2003;21(2):105-113. DOI: 10.2165/00019053-200321020-00003

8. Lapidus CS, Schwarz DF, Honig PJ. Atopic dermatitis in children: who cares? Who pays? J Am Acad Dermatol. 1993;28(5 Pt 1):699-703.

9. Lawson V, Lewis-Jones MS, Finlay AY, Reid P, Owens RG. The family impact of childhood atopic dermatitis: the Dermatitis Family Impact Questionnaire. Br J Dermatol. 1998;138(1):107-113. DOI: 10.1046/j.1365-2133.1998.02034.x 
10. Adamson AS. The economics burden of atopic dermatitis. Adv Exp Med Biol. 2017;1027:79-92. DOI: 10.1007/978-3-319-64804-0_8

11. Wollenberg A, Barbarot S, Bieber T, Christen-Zaech S, Deleuran M, Fink-Wagner A, et al. Consensusbased European guidelines for treatment of atopic eczema (atopic dermatitis) in adults and children: part I. J Eur Acad Dermatol Venereol. 2018;32(5):657-682. DOI: 10.1111/jdv.14891

12. Wollenberg A, Barbarot S, Bieber T, Christen-Zaech S, Deleuran M, Fink-Wagner A, et al. Consensusbased European guidelines for treatment of atopic eczema (atopic dermatitis) in adults and children: part II. J Eur Acad Dermatol Venereol. 2018;32(6):850-878. DOI: 10.1111/jdv.14888

13. Guyatt GH, Oxman AD, Vist GE, Kunz R, Falck-Ytter Y, Alonso-Coello P, et al. GRADE: an emerging consensus on rating quality of evidence and strength of recommendations. BMJ. 2008;336(7650):924926. DOI: 10.1136/bmj.39489.470347.AD

14. Guyatt G, Oxman AD, Akl EA, Kunz R, Vist G, Brozek J, et al. GRADE guidelines: 1. IntroductionGRADE evidence profiles and summary of findings tables. J Clin Epidemiol. 2011;64(4):383-394. DOI: 10.1016/j.jclinepi.2010.04.026

15. Davies E, Rogers NK, Lloyd-Lavery A, Grindlay DJC, Thomas KS. What's new in atopic eczema? An analysis of systematic reviews published in 2015. Part 1: epidemiology and methodology. Clin Exp Dermatol. 2018;43(4):375-379. DOI: 10.1111/ced.13377

16. Johansson SG, Bieber T, Dahl R, Friedmann PS, Lanier BQ, Lockey RF, et al. Revised nomenclature for allergy for global use: Report of the Nomenclature Review Committee of the World Allergy Organization, October 2003. J Allergy Clin Immunol. 2004;113(5):832-826. DOI: 10.1016/j.jaci.2003.12.591

17. Schäfer T, Krämer U, Vieluf D, Abeck D, Behrendt H, Ring J. The excess of atopic eczema in East Germany is related to the intrinsic type. Br J Dermatol. 2000;143(5):992-998. DOI: 10.1046/j.13652133.2000.03832.x

18. Böhme M, Wickman M, Lennart-Nordvall S, Svartengren M, Wahlgren CF. Family history and risk of atopic dermatitis in children up to 4 years. Clin Exp Allergy. 2003;33(9):1226-1231. DOI: 10.1046/j.13652222.2003.01749.x

19. Schmid-Grendelmeier P, Flückiger S, Disch R, Trautmann A, Wüthrich B, Blaser K, et al. IgE-mediated and $\mathrm{T}$ cell-mediated autoimmunity against manganese superoxide dismutase in atopic dermatitis. $\mathrm{J}$ Allergy Clin Immunol. 2005;115(5):1068-1075. DOI: 10.1016/j.jaci.2005.01.065

20. Sánchez J, Páez B, Macías A, Olmos C, de Falco A. Atopic dermatitis guideline. Position paper from the Latin American Society of Allergy, Asthma and Immunology. Rev Alerg Mex. 2014;61(3):178-211.

21. Mizrahi M. Arguments from expert opinion and persists bias. Argumentation. 2018;32(2):175-95. DOI: 10.1007/s10503-017-9434-x

22. Brożek JL, Bousquet J, Agache I, Agarwal A, Bachert C, Bosnic-Anticevich S, et al. Allergic Rhinitis and its Impact on Asthma (ARIA) guidelines-2016 revision. J Allergy Clin Immunol. 2017;140(4):950-958. DOI: $10.1016 /$ j.jaci.2017.03.050

23. Shamseer L, Moher D, Clarke M, Ghersi D, Liberati A, Petticrew M, et al. Preferred reporting items for systematic review and meta-analysis protocols (PRISMA-P) 2015: elaboration and explanation. BMJ. 2015;350:g7647. DOI: 10.1136/bmj.g7647

24. Okoli C, Pawlowski SD. The Delphi method as a research tool: an example, design considerations and applications. 2004;42(1):15-29. DOI: 10.1016/j.im.2003.11.002

25. Balshem H, Helfand M, Schünemann HJ, Oxman AD, Kunz R, Brozek J, et al. GRADE guidelines: 3. Rating the quality of evidence. J Clin Epidemiol. 2011;64(4):401-406. DOI: 10.1016/j.jclinepi.2010.07.015

26. Alonso-Coello P, Oxman AD, Moberg J, Brignardello-Petersen R, Akl EA, Davoli M, et al. GRADE Evidence to Decision (EtD) frameworks: a systematic and transparent approach to making well informed healthcare choices. 2: clinical practice guidelines. BMJ. 2016;353:i2089. DOI: 10.1136/bmj.i2089

27. Schünemann HJ, Mustafa R, Brozek J, Santesso N, Alonso-Coello P, Guyatt G, et al. GRADE Guidelines: 16. GRADE evidence to decision frameworks for tests in clinical practice and public health. J Clin Epidemiol. 2016;76:89-98. DOI: 10.1016/j.jclinepi.2016.01.032 
28. Thijs JL, Strickland I, Bruijnzeel-Koomen CAFM, Nierkens S, Giovannone B, Csomor E, et al. Moving toward endotypes in atopic dermatitis: identification of patient clusters based on serum biomarker analysis. J Allergy Clin Immunol. 2017;140(3):730-737. DOI: 10.1016/j.jaci.2017.03.023

29. Muraro A, Lemanske RF, Hellings PW, Akdis CA, Bieber T, Casale TB, et al. Precision medicine in patients with allergic diseases: airway diseases and atopic dermatitis-PRACTALL document of the European Academy of Allergy and Clinical Immunology and the American Academy of Allergy, Asthma \& Immunology. J Allergy Clin Immunol. 2016;137(5):1347-1358. DOI: 10.1016/j.jaci.2016.03.010

30. Orivuori L, Mustonen K, Roduit C, Braun-Fahrländer C, Dalphin JC, Genuneit J, et al. Immunoglobulin $A$ and immunoglobulin $G$ antibodies against $\beta$-lactoglobulin and gliadin at age 1 associate with immunoglobulin E sensitization at age 6. Pediatr Allergy Immunol. 2014;25(4):329-337. DOI: 10.1111/ pai.12246

31. von Berg A, Filipiak-Pittroff B, Schulz H, Hoffmann U, Link E, Sußmann M, et al. Allergic manifestation 15 years after early intervention with hydrolyzed formulas-the GINI Study. Allergy. 2016;71(2):210-219. DOI: 10.1111/all.12790

32. Simpson EL, Chalmers JR, Hanifin JM, Thomas KS, Cork MJ, McLean WH, et al. Emollient enhancement of the skin barrier from birth offers effective atopic dermatitis prevention. J Allergy Clin Immunol. 2014;134(4):818-823. DOI: 10.1016/j.jaci.2014.08.005

33. Horimukai K, Morita K, Narita M, Kondo M, Kitazawa H, Nozaki M, et al. Application of moisturizer to neonates prevents development of atopic dermatitis. J Allergy Clin Immunol. 2014;134(4):824-830. DOI: 10.1016/j.jaci.2014.07.060

34. Chalmers JR, Haines RH, Mitchell EJ, Thomas KS, Brown SJ, Ridd M, et al. Effectiveness and costeffectiveness of daily all-over-body application of emollient during the first year of life for preventing atopic eczema in high-risk children (The BEEP trial): protocol for a randomised controlled trial. Trials. 2017;18(1):343. DOI: 10.1186/s13063-017-2031-3

35. Tiplica GS, Kaszuba A, Malinauskiené L, Konno P, Boralevi F, Garrigue E, et al. Prevention of flares in children with atopic dermatitis with regular use of an emollient containing glycerol and paraffin: a randomized controlled study. Pediatr Dermatol. 2017;34(3):282-289. DOI: 10.1111/pde.13113

36. Åkerström U, Reitamo S, Langeland T, Berg M, Rustad L, Korhonen L, et al. Comparison of moisturizing creams for the prevention of atopic dermatitis relapse: a randomized double-blind controlled multicentre clinical trial. Acta Derm Venereol. 2015;95(5):587-592. DOI: 10.2340/00015555-2051

37. Fukuie T, Hirakawa S, Narita M, Nomura I, Matsumoto K, Tokura Y, et al. Potential preventive effects of proactive therapy on sensitization in moderate to severe childhood atopic dermatitis: a randomized, investigator-blinded, controlled study. J Dermatol. 2016;43(11):1283-1292. DOI: 10.1111/1346-8138.13408

38. Muehleisen B, Gallo RL. Vitamin D in allergic disease: shedding light on a complex problem. J Allergy Clin Immunol. 2013;131(2):324-329. DOI: 10.1016/j.jaci.2012.12.1562

39. Camargo CA, Ganmaa D, Sidbury R, Erdenedelger K, Radnaakhand N, Khandsuren B. Randomized trial of vitamin $\mathrm{D}$ supplementation for winter-related atopic dermatitis in children. J Allergy Clin Immunol. 2014;134(4):831-835. DOI: 10.1016/j.jaci.2014.08.002

40. Sidbury R, Sullivan AF, Thadhani RI, Camargo CA. Randomized controlled trial of vitamin D supplementation for winter-related atopic dermatitis in Boston: a pilot study. $\mathrm{Br} \mathrm{J}$ Dermatol. 2008;159(1):245-247. DOI: 10.1111/j.1365-2133.2008.08601.x

41. Sánchez J, Sánchez A, Cardona R. Particular characteristics of atopic eczema in tropical environments. The Tropical Environment Control for Chronic Eczema and Molecular Assessment (TECCEMA) cohort study. An Bras Dermatol. 2017;92(2):177-183. DOI: 10.1590/abd1806-4841.20175140

42. Solman L, Lloyd-Lavery A, Grindlay DJC, Rogers NK, Thomas KS, Harman KE. What's new in atopic eczema? An analysis of systematic reviews published in 2016. Part 1: treatment and prevention. Clin Exp Dermatol. 2019;44(4):363-369. DOI: 10.1111/ced.13885

43. Kim JP, Chao LX, Simpson EL, Silverberg JI. Persistence of atopic dermatitis (AD): a systematic review and meta-analysis. J Am Acad Dermatol. 2016;75(4):681-687. DOI: 10.1016/j.jaad.2016.05.028 
44. Thorsteinsdottir S, Stokholm J, Thyssen JP, Nørgaard S, Thorsen J, Chawes BL, et al. Genetic, clinical, and environmental factors associated with persistent atopic dermatitis in childhood. JAMA Dermatol. 2018;155(1):50-57. DOI: 10.1001/jamadermatol.2018.4061

45. Pajno GB, Peroni DG, Barberio G, Pietrobelli A, Boner AL. Predictive features for persistence of atopic dermatitis in children. Pediatr Allergy Immunol. 2003;14(4):292-295. DOI: 10.1034/j.13993038.2003.00060.x

46. Guo MM, Tseng WN, Ou CY, Hsu TY, Kuo HC, Yang KD. Predictive factors of persistent infantile atopic dermatitis up to 6 years old in Taiwan: a prospective birth cohort study. Allergy. 2015;70(11):1477-1484. DOI: 10.1111/all.12706

47. Domínguez-Bello MG, Costello EK, Contreras M, Magris M, Hidalgo G, Fierer N, et al. Delivery mode shapes the acquisition and structure of the initial microbiota across multiple body habitats in newborns. Proc Natl Acad Sci U S A. 2010;107(26):11971-11975. DOI: 10.1073/pnas.1002601107

48. Park YJ, Lee HK. The role of skin and orogenital microbiota in protective immunity and chronic immunemediated inflammatory disease. Front Immunol. 2017;8:1955. DOI: 10.3389/fimmu.2017.01955

49. Baldwin HE, Bhatia ND, Friedman A, Eng RM, Seite S. The Role of cutaneous microbiota harmony in maintaining a functional skin barrier. J Drugs Dermatol. 2017;16(1):12-18. DOI: 10.25251/skin.1.supp.138

50. Nakatsuji T, Chen TH, Narala S, Chun KA, Two AM, Yun T, et al. Antimicrobials from human skin commensal bacteria protect against. Sci Transl Med. 2017;9(378). DOI: 10.1126/scitranslmed.aah4680

51. Di Domenico EG, Cavallo I, Bordignon V, Prignano G, Sperduti I, Gurtner A, et al. Inflammatory cytokines and biofilm production sustain Staphylococcus aureus outgrowth and persistence: a pivotal interplay in the pathogenesis of atopic dermatitis. Sci Rep. 2018;8(1):9573. DOI: 10.1038/s41598-018-27421-1

52. Jinnestål CL, Belfrage E, Bäck O, Schmidtchen A, Sonesson A. Skin barrier impairment correlates with cutaneous Staphylococcus aureus colonization and sensitization to skin-associated microbial antigens in adult patients with atopic dermatitis. Int J Dermatol. 2014;53(1):27-33. DOI: 10.1111/ijd.12198

53. Cavalcante FS, Abad ED, Lyra YC, Saintive SB, Ribeiro M, Ferreira DC, et al. High prevalence of methicillin resistance and PVL genes among Staphylococcus aureus isolates from the nares and skin lesions of pediatric patients with atopic dermatitis. Braz J Med Biol Res. 2015;48(7):588-594. DOI: 10.1590/1414-431X20154221

54. Birnie AJ, Bath-Hextall FJ, Ravenscroft JC, Williams HC. Interventions to reduce Staphylococcus aureus in the management of atopic eczema. Cochrane Database Syst Rev. 2008(3):CD003871. DOI: 10.1002/14651858.CD003871.pub3

55. Yeşilova Y, Çalka Ö, Akdeniz N, Berktaş M. Effect of probiotics on the treatment of children with atopic dermatitis. Ann Dermatol. 2012;24(2):189-193. DOI: 10.5021/ad.2012.24.2.189

56. Fiocchi A, Pawankar R, Cuello-Garcia C, Ahn K, Al-Hammadi S, Agarwal A, et al. World Allergy Organization-McMaster University Guidelines for Allergic Disease Prevention (GLAD-P): Probiotics. World Allergy Organ J. 2015;8(1):4. DOI: 10.1186/s40413-015-0055-2

57. Niccoli AA, Artesi AL, Candio F, Ceccarelli S, Cozzali R, Ferraro L, et al. Preliminary results on clinical effects of probiotic Lactobacillus salivarius LS01 in children affected by atopic dermatitis. J Clin Gastroenterol. 2014;48(Suppl 1):S34-S36. DOI: 10.1097/MCG.0000000000000233

58. Huang R, Ning H, Shen M, Li J, Zhang J, Chen X. Probiotics for the treatment of atopic dermatitis in children: a systematic review and meta-analysis of randomized controlled trials. Front Cell Infect Microbiol. 2017;7:392. DOI: 10.3389/fcimb.2017.00392

59. Wickens K, Barthow C, Mitchell EA, Stanley TV, Purdie G, Rowden J, et al. Maternal supplementation alone with Lactobacillus rhamnosus HN001 during pregnancy and breastfeeding does not reduce infant eczema. Pediatr Allergy Immunol. 2018;29(3):296-302. DOI: 10.1111/pai.12874

60. Boyle RJ, Bath-Hextall FJ, Leonardi-Bee J, Murrell DF, Tang ML. Probiotics for treating eczema. Cochrane Database Syst Rev. 2008(4):CD006135. DOI: 10.1002/14651858.CD006135.pub3

61. Yang HJ, Min TK, Lee HW, Pyun BY. Efficacy of probiotic therapy on atopic dermatitis in children: a randomized, double-blind, placebo-controlled trial. Allergy Asthma Immunol Res. 2014;6(3):208-215. DOI: 10.4168/aair.2014.6.3.208 
62. Sánchez J, Sánchez A. Epidemiology of food allergy in Latin America. Allergol Immunopathol (Madr). 2015;43(2):185-195. DOI: 10.1016/j.aller.2013.07.001

63. Sánchez J, Sánchez A. Epidemiologic studies about food allergy and food sensitization in tropical countries. Results and limitations. Allergol Immunopathol (Madr). 2019;47(4):401-408. DOI: 10.1016/j.aller.2018.11.001

64. Estrada-Reyes E, Pardo-Castañeda MG, Toledo-Bahena ME, Lerma-Ortiz ML, Del Río-Navarro B, Nava-Ocampo AA. A case-control study of food hyper-sensitivity, timing of weaning and family history of allergies in young children with atopic dermatitis. Allergol Immunopathol (Madr). 2007;35(3):101-104. DOI: $10.1157 / 13106777$

65. Jøhnke H, Norberg LA, Vach W, HøstA, Andersen KE. Patterns of sensitization in infants and its relation to atopic dermatitis. Pediatr Allergy Immunol. 2006;17(8):591-600. DOI: 10.1111/j.1399-3038.2006.00453.x

66. Roerdink EM, Flokstra-de Blok BM, Blok JL, Schuttelaar ML, Niggemann B, Werfel T, et al. Association of food allergy and atopic dermatitis exacerbations. Ann Allergy Asthma Immunol. 2016;116(4):334-338. DOI: 10.1016/j.anai.2016.01.022

67. Rennick GJ, Moore E, Orchard DC. Skin prick testing to food allergens in breast-fed young infants with moderate to severe atopic dermatitis. Australas J Dermatol. 2006;47(1):41-45. DOI: 10.1111/j.14400960.2006.00221.x

68. Levy SA, Dortas Junior SD, Pires AH, Abe AT, Valle SO, Coelho VP, et al. Atopy patch test (APT) in the diagnosis of food allergy in children with atopic dermatitis. An Bras Dermatol. 2012;87(5):724-728. DOI: 10.1590/s0365-05962012000500009

69. David TJ. Anaphylactic shock during elimination diets for severe atopic eczema. Arch Dis Child. 1984;59(10):983-986. DOI: 10.1136/adc.59.10.983

70. Barbi E, Gerarduzzi T, Longo G, Ventura A. Fatal allergy as a possible consequence of long-term elimination diet. Allergy. 2004;59(6):668-669. DOI: 10.1111/j.1398-9995.2004.00398.x

71. Flinterman AE, Knulst AC, Meijer Y, Bruijnzeel-Koomen CA, Pasmans SG. Acute allergic reactions in children with AEDS after prolonged cow's milk elimination diets. Allergy. 2006;61(3):370-374. DOI: 10.1111/j.1398-9995.2006.01018.x

72. Chang A, Robison R, Cai M, Singh AM. Natural history of food-triggered atopic dermatitis and development of immediate reactions in children. J Allergy Clin Immunol Pract. 2016;4(2):229-236. DOI: 10.1016/j.jaip.2015.08.006

73. Fleischer DM, Bock SA, Spears GC, Wilson CG, Miyazawa NK, Gleason MC, et al. Oral food challenges in children with a diagnosis of food allergy. J Pediatr. 2011;158(4):578-583. DOI: 10.1016/j.jpeds.2010.09.027

74. Eapen AA, Kloepfer KM, Leickly FE, Slaven JE, Vitalpur G. Oral food challenge failures among foods restricted because of atopic dermatitis. Ann Allergy Asthma Immunol. 2019;122(2):193-197. DOI: 10.1016/j.anai.2018.10.012

75. Santer M, Rumsby K, Ridd MJ, Francis NA, Stuart B, Chorozoglou M, et al. Adding emollient bath additives to standard eczema management for children with eczema: the BATHE RCT. Health Technol Assess. 2018;22(57):1-116.

76. Antonijević MD, Novac O, O’Hagan BM. Can emollients of similar composition be assumed to be therapeutically equivalent: a comparison of skin occlusivity and emulsion microstructure. Clin Cosmet Investig Dermatol. 2018;11:461-465. DOI: 10.2147/CCID.S176943

77. Jung HJ, Bae JY, Kim JE, Na CH, Park GH, Bae YI, et al. Survey of disease awareness, treatment behavior and treatment satisfaction in patients with atopic dermatitis in Korea: a multicenter study. J Dermatol. 2018;45(10):1172-1180. DOI: 10.1111/1346-8138.14540

78. Sala-Cunill A, Lazaro M, Herráez L, Quiñones MD, Moro-Moro M, Sánchez I, et al. Basic skin care and topical therapies for atopic dermatitis: essential approaches and beyond. J Investig Allergol Clin Immunol. 2018;28(6):379-391. DOI: 10.18176/jiaci.0293

79. Eriksson S, van der Plas MJA, Mörgelin M, Sonesson A. Antibacterial and antibiofilm effects of sodium hypochlorite against Staphylococcus aureus isolates derived from patients with atopic dermatitis. $\mathrm{Br} \mathrm{J}$ Dermatol. 2017;177(2):513-521. DOI: 10.1111/bjd.15410 
Sánchez $\mathrm{J}$ et al. Systematic review about interventions in dermatitis

80. Harris V, Smith SD. Lifting the biofilm lid on the antibacterial and antibiofilm effects of sodium hypochlorite against Staphylococcus aureus in atopic dermatitis. Br J Dermatol. 2017;177(2):347-348. DOI: 10.1111/ bjd.15692

81. Asch S, Vork DL, Joseph J, Major-Elechi B, Tollefson MM. Comparison of bleach, acetic acid, and other topical anti-infective treatments in pediatric atopic dermatitis: a retrospective cohort study on antibiotic exposure. Pediatr Dermatol. 2019;36(1):115-120. DOI: 10.1111/pde.13663

82. Church MK, Maurer M. H1-antihistamines and itch in atopic dermatitis. Exp Dermatol. 2015;24(5):332-333.

83. Ohsawa $\mathrm{Y}$, Hirasawa $\mathrm{N}$. The role of histamine $\mathrm{H} 1$ and $\mathrm{H} 4$ receptors in atopic dermatitis: from basic research to clinical study. Allergol Int. 2014;63(4):533-542. DOI: 10.2332/allergolint.13-RA-0675

84. Munday J, Bloomfield R, Goldman M, Robey H, Kitowska GJ, Gwiezdziski Z, et al. Chlorpheniramine is no more effective than placebo in relieving the symptoms of childhood atopic dermatitis with a nocturnal itching and scratching component. Dermatology. 2002;205(1):40-45. DOI: 10.1159/000063138

85. Wahlgren CF, Hägermark $O$, Bergström R. The antipruritic effect of a sedative and a non-sedative antihistamine in atopic dermatitis. Br J Dermatol. 1990;122(4):545-551. DOI: 10.1111/j.1365-2133.1990. tb14732.x

86. Frosch PJ, Schwanitz HJ, Macher E. A double blind trial of $\mathrm{H} 1$ and $\mathrm{H} 2$ receptor antagonists in the treatment of atopic dermatitis. Arch Dermatol Res. 1984;276(1):36-40. DOI: 10.1007/bf00412560

87. Savin JA, Dow R, Harlow BJ, Massey H, Yee KF. The effect of a new non-sedative H1-receptor antagonist (LN2974) on the itching and scratching of patients with atopic eczema. Clin Exp Dermatol. 1986;11(6):600602. DOI: 10.1111/j.1365-2230.1986.tb00515.x

88. Hannuksela M, Kalimo K, Lammintausta K, Mattila T, Turjanmaa K, Varjonen E, et al. Dose ranging study: cetirizine in the treatment of atopic dermatitis in adults. Ann Allergy. 1993;70(2):127-133.

89. Langeland T, Fagertun HE, Larsen S. Therapeutic effect of loratadine on pruritus in patients with atopic dermatitis. A multi-crossover-designed study. Allergy. 1994;49(1):22-26. DOI: 10.1111/j.1398-9995.1994. tb00768.x

90. La Rosa M, Ranno C, Musarra I, Guglielmo F, Corrias A, Bellanti JA. Double-blind study of cetirizine in atopic eczema in children. Ann Allergy. 1994;73(2):117-122.

91. Yamanaka K, Motomura E, Noro Y, Umeda K, Morikawa T, Umeda-Togami K, et al. Olopatadine, a nonsedating $\mathrm{H} 1$ antihistamine, decreases the nocturnal scratching without affecting sleep quality in atopic dermatitis. Exp Dermatol. 2015;24(3):227-229. DOI: 10.1111/exd.12630

92. Kawashima M, Tango T, Noguchi T, Inagi M, Nakagawa H, Harada S. Addition of fexofenadine to a topical corticosteroid reduces the pruritus associated with atopic dermatitis in a 1-week randomized, multicentre, double-blind, placebo-controlled, parallel-group study. Br J Dermatol. 2003;148(6):12121221. DOI: 10.1046/j.1365-2133.2003.05293.x

93. Church MK, Maurer M, Simons FE, Bindslev-Jensen C, van Cauwenberge P, Bousquet J, et al. Risk of first-generation $\mathrm{H}(1)$-antihistamines: a GA(2)LEN position paper. Allergy. 2010;65(4):459-466. DOI: 10.1111/j.1398-9995.2009.02325.x

94. Hamilton JD, Suárez-Fariñas M, Dhingra N, Cardinale I, Li X, Kostic A, et al. Dupilumab improves the molecular signature in skin of patients with moderate-to-severe atopic dermatitis. J Allergy Clin Immunol. 2014;134(6):1293-1300. DOI: 10.1016/j.jaci.2014.10.013

95. Beck LA, Thaçi D, Hamilton JD, Graham NM, Bieber T, Rocklin R, et al. Dupilumab treatment in adults with moderate-to-severe atopic dermatitis. N Engl J Med. 2014;371(2):130-139. DOI: 10.1056/ NEJMoa1314768

96. Silverberg JI, Simpson EL, Ardeleanu M, Thaçi D, Barbarot S, Bagel J, et al. Dupilumab provides important clinical benefits to patients with atopic dermatitis who do not achieve clear or almost clear skin according to the Investigator's Global Assessment: a pooled analysis of data from 2 phase III trials. $\mathrm{Br} \mathrm{J}$ Dermatol. 2019;181(1):80-87. DOI: 10.1111/bjd.17791

97. Storan ER, Woolf RT, Smith $\mathrm{CH}$, Pink AE. Clearance of molluscum contagiosum virus infection in patients with atopic eczema treated with dupilumab. Br J Dermatol. 2019;181(2):385-386. DOI: 10.1111/bjd.17712 
98. Blauvelt A, Rosmarin D, Bieber T, Simpson EL, Bagel J, Worm M, et al. Improvement of atopic dermatitis with dupilumab occurs equally well across different anatomic regions: data from phase 3 clinical trials. Br J Dermatol. 2019;181(1):196-197. DOI: 10.1111/bjd.17703

99. Tintle S, Shemer A, Suárez-Fariñas M, Fujita H, Gilleaudeau P, Sullivan-Whalen M, et al. Reversal of atopic dermatitis with narrow-band UVB phototherapy and biomarkers for therapeutic response. J Allergy Clin Immunol. 2011;128(3):583-593. DOI: 10.1016/j.jaci.2011.05.042

100. Clayton TH, Clark SM, Turner D, Goulden V. The treatment of severe atopic dermatitis in childhood with narrowband ultraviolet B phototherapy. Clin Exp Dermatol. 2007;32(1):28-33. DOI: 10.1111/j.13652230.2006.02292.x

101. Meduri NB, Vandergriff $T$, Rasmussen $H$, Jacobe $H$. Phototherapy in the management of atopic dermatitis: a systematic review. Photodermatol Photoimmunol Photomed. 2007;23(4):106-112. DOI: 10.1111/j.1600-0781.2007.00291.x

102. Brownell J, Wang S, Tsoukas MM. Compliance and phototherapy. Clin Dermatol. 2016;34(5):582-586. DOI: 10.1016/j.clindermatol.2016.05.007

103. Cline A, Unrue EL, Collins A, Feldman SR. Adherence to a novel home phototherapy system with integrated features. Dermatol Online J. 2019;25(3). Available at: https://www.clarifymed.com/wp-content/ uploads/DOJ-Adherence-Publication-March-2019.pdf

104. Drucker AM, Eyerich K, de Bruin-Weller MS, Thyssen JP, Spuls PI, Irvine AD, et al. Use of systemic corticosteroids for atopic dermatitis: International Eczema Council consensus statement. Br J Dermatol. 2018;178(3):768-775. DOI: 10.1111/bjd.15928

105. Roekevisch E, Spuls PI, Kuester D, Limpens J, Schmitt J. Efficacy and safety of systemic treatments for moderate-to-severe atopic dermatitis: a systematic review. J Allergy Clin Immunol. 2014;133(2):429438. DOI: 10.1016/j.jaci.2013.07.049

106. Yu SH, Drucker AM, Lebwohl M, Silverberg JI. A systematic review of the safety and efficacy of systemic corticosteroids in atopic dermatitis. J Am Acad Dermatol. 2018;78(4):733-740. DOI: 10.1016/j. jaad.2017.09.074

107. Berth-Jones J, Takwale A, Tan E, Barclay G, Agarwal S, Ahmed I, et al. Azathioprine in severe adult atopic dermatitis: a double-blind, placebo-controlled, crossover trial. Br J Dermatol. 2002;147(2):324330. DOI: 10.1046/j.1365-2133.2002.04989.x

108. Berth-Jones J, Graham-Brown RA, Marks R, Camp RD, English JS, Freeman K, et al. Long-term efficacy and safety of cyclosporin in severe adult atopic dermatitis. Br J Dermatol. 1997;136(1):76-81. DOI: 10.1046/j.1365-2133.1997.d01-1146.x

109. Salek MS, Finlay AY, Luscombe DK, Allen BR, Berth-Jones J, Camp RD, et al. Cyclosporin greatly improves the quality of life of adults with severe atopic dermatitis. A randomized, double-blind, placebocontrolled trial. Br J Dermatol. 1993;129(4):422-430. DOI: 10.1111/j.1365-2133.1993.tb03170.x

110. van Joost T, Heule F, Korstanje M, van den Broek MJ, Stenveld HJ, van Vloten WA. Cyclosporin in atopic dermatitis: a multicentre placebo-controlled study. Br J Dermatol. 1994;130(5):634-640. DOI: 10.1111/ j.1365-2133.1994.tb13111.x

111. Sowden JM, Berth-Jones J, Ross JS, Motley RJ, Marks R, Finlay AY, et al. Double-blind, controlled, crossover study of cyclosporin in adults with severe refractory atopic dermatitis. Lancet. 1991;338(8760):137-140. DOI: 10.1016/0140-6736(91)90134-b

112. Haeck IM, Knol MJ, Ten Berge O, van Velsen SG, de Bruin-Weller MS, Bruijnzeel-Koomen CA. Entericcoated mycophenolate sodium versus cyclosporin A as long-term treatment in adult patients with severe atopic dermatitis: a randomized controlled trial. J Am Acad Dermatol. 2011;64(6):1074-84. DOI: 10.1016/j.jaad.2010.04.027

113. Koppelhus U, Poulsen J, Grunnet N, Deleuran MS, Obitz E. Cyclosporine and extracorporeal photopheresis are equipotent in treating severe atopic dermatitis: a randomized cross-over study comparing two efficient treatment modalities. Front Med (Lausanne). 2014;1:33. DOI: 10.3389/ fmed.2014.00033 
114. Zonneveld IM, De Rie MA, Beljaards RC, Van Der Rhee HJ, Wuite J, Zeegelaar J, et al. The long-term safety and efficacy of cyclosporin in severe refractory atopic dermatitis: a comparison of two dosage regimens. Br J Dermatol. 1996;135(Suppl 48):15-20. DOI: 10.1111/j.1365-2133.1996.tb00704.x

115. Granlund H, Erkko P, Remitz A, Langeland T, Helsing P, Nuutinen M, et al. Comparison of cyclosporin and UVAB phototherapy for intermittent one-year treatment of atopic dermatitis. Acta Derm Venereol. 2001;81(1):22-27. DOI: 10.1080/00015550120235

116. Harper JI, Ahmed I, Barclay G, Lacour M, Hoeger P, Cork MJ, et al. Cyclosporin for severe childhood atopic dermatitis: short course versus continuous therapy. $\mathrm{Br} J$ Dermatol. 2000;142(1):52-58. DOI: 10.1046/j.1365-2133.2000.03241.x

117. Czech W, Bräutigam M, Weidinger G, Schöpf E. A body-weight-independent dosing regimen of cyclosporine microemulsion is effective in severe atopic dermatitis and improves the quality of life. J Am Acad Dermatol. 2000;42(4):653-659. DOI: 10.1067/mjd.2000.103815

118. Bunikowski R, Gerhold K, Bräutigam M, Hamelmann E, Renz H, Wahn U. Effect of low-dose cyclosporin a microemulsion on disease severity, IL-6, IL-8 and tumor necrosis factor alpha production in severe pediatric atopic dermatitis. Int Arch Allergy Immunol. 2001;125(4):344-348. DOI: 10.1159/000053836

119. Bunikowski R, Staab D, Kussebi F, Bräutigam M, Weidinger G, Renz H, et al. Low-dose cyclosporin A microemulsion in children with severe atopic dermatitis: clinical and immunological effects. Pediatr Allergy Immunol. 2001;12(4):216-223. DOI: 10.1034/j.1399-3038.2001.012004216.x

120. Totri CR, Eichenfield LF, Logan K, Proudfoot L, Schmitt J, Lara-Corrales I, et al. Prescribing practices for systemic agents in the treatment of severe pediatric atopic dermatitis in the US and Canada: the PeDRA TREAT survey. J Am Acad Dermatol. 2017;76(2):281-285. DOI: 10.1016/j.jaad.2016.09.021

121. Weatherhead SC, Wahie S, Reynolds NJ, Meggitt SJ. An open-label, dose-ranging study of methotrexate for moderate-to-severe adult atopic eczema. Br J Dermatol. 2007;156(2):346-351. DOI: 10.1111/j.13652133.2006.07686.x

122. Goujon C, Viguier M, Staumont-Sallé D, Bernier C, Guillet G, Lahfa M, et al. Methotrexate versus cyclosporine in adults with moderate-to-severe atopic dermatitis: a phase III randomized noninferiority trial. J Allergy Clin Immunol Pract. 2018;6(2):562-569. DOI: 10.1016/j.jaip.2017.07.007

123. Law Ping Man S, Bouzillé G, Beneton N, Safa G, Dupuy A, Droitcourt C. Drug survival and postdrug survival of first-line immunosuppressive treatments for atopic dermatitis: comparison between methotrexate and cyclosporine. J Eur Acad Dermatol Venereol. 2018;32(8):1327-1335. DOI: 10.1111/jdv.14880

124. El-Khalawany MA, Hassan H, Shaaban D, Ghonaim N, Eassa B. Methotrexate versus cyclosporine in the treatment of severe atopic dermatitis in children: a multicenter experience from Egypt. Eur J Pediatr. 2013;172(3):351-356. DOI: 10.1007/s00431-012-1893-3

125. Meggitt SJ, Gray JC, Reynolds NJ. Azathioprine dosed by thiopurine methyltransferase activity for moderateto-severe atopic eczema: a double-blind, randomised controlled trial. Lancet. 2006;367(9513):839-846. DOI: 10.1016/S0140-6736(06)68340-2

126. Schram ME, Roekevisch E, Leeflang MM, Bos JD, Schmitt J, Spuls PI. A randomized trial of methotrexate versus azathioprine for severe atopic eczema. J Allergy Clin Immunol. 2011;128(2):353-359. DOI: 10.1016/j.jaci.2011.03.024

127. Ballester I, Silvestre JF, Pérez-Crespo M, Lucas A. Severe adult atopic dermatitis: treatment with mycophenolate mofetil in 8 patients. Actas Dermosifiliogr. 2009;100(10):883-887. DOI: 10.1016/S15782190(09)70559-1

128. Fallah Arani S, Waalboer-Spuij R, Nijsten T, Neumann HA, Thio B. Enteric-coated mycophenolate sodium in psoriasis vulgaris: an open pilotstudy. JDermatolog Treat. 2014;25(1):46-49. DOI: 10.3109/09546634.2012.723124

129. Grundmann-Kollmann M, Podda M, Ochsendorf F, Boehncke WH, Kaufmann R, Zollner TM. Mycophenolate mofetil is effective in the treatment of atopic dermatitis. Arch Dermatol. 2001;137(7):870873. DOI: 10-1001/pubs.Arch Dermatol.-ISSN-0003-987x-137-7-dst10044

130. Murray ML, Cohen JB. Mycophenolate mofetil therapy for moderate to severe atopic dermatitis. Clin Exp Dermatol. 2007;32(1):23-27. DOI: 10.1111/j.1365-2230.2006.02290.x 
131. Dias-PolakD, Bergman R, Avitan-Hersh E. Mycophenolate mofetil therapy in adult patients with recalcitrant atopic dermatitis. J Dermatolog Treat. 2019;30(1):49-51. DOI: 10.1080/09546634.2018.1468068

132. Heller M, Shin HT, Orlow SJ, Schaffer JV. Mycophenolate mofetil for severe childhood atopic dermatitis: experience in 14 patients. Br J Dermatol. 2007;157(1):127-132. DOI: 10.1111/j.1365-2133.2007.07947.x

133. Paller AS, Tom WL, Lebwohl MG, Blumenthal RL, Boguniewicz M, Call RS, et al. Efficacy and safety of crisaborole ointment, a novel, nonsteroidal phosphodiesterase 4 (PDE4) inhibitor for the topical treatment of atopic dermatitis (AD) in children and adults. J Am Acad Dermatol. 2016;75(3):494-503. DOI: $10.1016 /$ j.jaad.2016.05.046

134. Draelos ZD, Stein Gold LF, Murrell DF, Hughes MH, Zane LT. Post hoc analyses of the effect of crisaborole topical ointment, $2 \%$ on atopic dermatitis: associated pruritus from phase 1 and 2 clinical studies. J Drugs Dermatol. 2016;15(2):172-176.

135. Zane LT, Hughes MH, Shakib S. Tolerability of crisaborole ointment for application on sensitive skin areas: a randomized, double-blind, vehicle-controlled study in healthy volunteers. Am J Clin Dermatol. 2016;17(5):519-526. DOI: 10.1007/s40257-016-0204-6

136. de Bruin-Weller M, Thaçi D, Smith $\mathrm{CH}$, Reich K, Cork MJ, Radin A, et al. Dupilumab with concomitant topical corticosteroid treatment in adults with atopic dermatitis with an inadequate response or intolerance to ciclosporin A or when this treatment is medically inadvisable: a placebo-controlled, randomized phase III clinical trial (LIBERTY AD CAFÉ). Br J Dermatol. 2018;178(5):1083-1101. DOI: 10.1111/bjd.16156

137. Fukuda K, Ishida W, Kishimoto T, Fukushima A. Development of conjunctivitis with a conjunctival proliferative lesion in a patient treated with dupilumab for atopic dermatitis. Allergol Int. 2019;68(3):383384. DOI: 10.1016/j.alit.2018.12.012 


\section{Supplementary material 1. Systematic review Check List from the PRIS-}

MA statement for the dermatitis-SLAAI guideline review of 10 interventions

Table present, is kindly offered freely for the PRISMA Group (2009) (for more information, visit www.prisma-statement.org). We highlight those recommendations that we did not make with red.

\begin{tabular}{|c|c|c|c|}
\hline Section/topic & \# & PRISMA Checklist item & $\begin{array}{l}\text { Reported } \\
\text { on page \# }\end{array}$ \\
\hline \multicolumn{4}{|l|}{ TITLE } \\
\hline Title & 1 & Identify the report as a systematic review, meta-analysis, or both. & 1 \\
\hline \multicolumn{4}{|l|}{ ABSTRACT } \\
\hline Structured summary & 2 & $\begin{array}{l}\text { Provide a structured summary including, as applicable: background; } \\
\text { objectives; data sources; study eligibility criteria, participants, and } \\
\text { interventions; study appraisal and synthesis methods; results; limita- } \\
\text { tions; conclusions and implications of key findings; systematic review } \\
\text { registration number. }\end{array}$ & 1 \\
\hline \multicolumn{4}{|l|}{ INTRODUCTION } \\
\hline Rationale & 3 & $\begin{array}{l}\text { Describe the rationale for the review in the context of what is already } \\
\text { known. }\end{array}$ & 2 \\
\hline Objectives & 4 & $\begin{array}{l}\text { Provide an explicit statement of questions being addressed with refer- } \\
\text { ence to participants, interventions, comparisons, outcomes, and study } \\
\text { design (PICOS). }\end{array}$ & $\begin{array}{l}3 \text { and } 4 \\
\text { Suppl } 2\end{array}$ \\
\hline \multicolumn{4}{|c|}{ ( } \\
\hline Protocol and registration & 5 & $\begin{array}{l}\text { Indicate if a review protocol exists, if and where it can be accessed } \\
\text { (e.g., Web address), and, if available, provide registration information } \\
\text { including registration number. }\end{array}$ & No register \\
\hline Eligibility criteria & 6 & $\begin{array}{l}\text { Specify study characteristics (e.g., PICOS, length of follow-up) and } \\
\text { report characteristics (e.g., years considered, language, publication } \\
\text { status) used as criteria for eligibility, giving rationale. }\end{array}$ & 3 and 4 \\
\hline Information sources & 7 & $\begin{array}{l}\text { Describe all information sources (e.g., databases with dates of cov- } \\
\text { erage, contact with study authors to identify additional studies) in the } \\
\text { search and date last searched. }\end{array}$ & 4 \\
\hline Search & 8 & $\begin{array}{l}\text { Present full electronic search strategy for at least one database, } \\
\text { including any limits used, such that it could be repeated. }\end{array}$ & $4^{*}$ \\
\hline Study selection & 9 & $\begin{array}{l}\text { State the process for selecting studies (i.e., screening, eligibility, } \\
\text { included in systematic review, and, if applicable, included in the } \\
\text { meta-analysis). }\end{array}$ & 4 \\
\hline Data collection process & 10 & $\begin{array}{l}\text { Describe method of data extraction from reports (e.g., piloted forms, } \\
\text { independently, in duplicate) and any processes for obtaining and } \\
\text { confirming data from investigators. }\end{array}$ & 4 \\
\hline Data items & 11 & $\begin{array}{l}\text { List and define all variables for which data were sought (e.g., PICOS, } \\
\text { funding sources) and any assumptions and simplifications made. }\end{array}$ & $4^{\star *}$ \\
\hline $\begin{array}{l}\text { Risk of bias in individual } \\
\text { studies }\end{array}$ & 12 & $\begin{array}{l}\text { Describe methods used for assessing risk of bias of individual studies } \\
\text { (including specification of whether this was done at the study or } \\
\text { outcome level), and how this information is to be used in any data } \\
\text { synthesis. }\end{array}$ & 4 and $5^{\star \star \star}$ \\
\hline Summary measures & 13 & $\begin{array}{l}\text { State the principal summary measures (e.g., risk ratio, difference in } \\
\text { means). }\end{array}$ & \\
\hline
\end{tabular}




\begin{tabular}{|c|c|c|c|}
\hline Synthesis of results & 14 & $\begin{array}{l}\text { Describe the methods of handling data and combining results of } \\
\text { studies, if done, including measures of consistency (e.g., I2) for each } \\
\text { meta-analysis. }\end{array}$ & \\
\hline Risk of bias across studies & 15 & $\begin{array}{l}\text { Specify any assessment of risk of bias that may affect the cumulative } \\
\text { evidence (e.g., publication bias, selective reporting within studies). }\end{array}$ & Suppl $1^{* * *}$ \\
\hline Additional analyses & 16 & $\begin{array}{l}\text { Describe methods of additional analyses (e.g., sensitivity or subgroup } \\
\text { analyses, meta-regression), if done, indicating which were pre-spec- } \\
\text { ified. }\end{array}$ & No apply \\
\hline \multicolumn{4}{|l|}{ RESULTS } \\
\hline Study selection & 17 & $\begin{array}{l}\text { Give numbers of studies screened, assessed for eligibility, and includ- } \\
\text { ed in the review, with reasons for exclusions at each stage, ideally } \\
\text { with a flow diagram. }\end{array}$ & Suppl 2 \\
\hline Study characteristics & 18 & $\begin{array}{l}\text { For each study, present characteristics for which data were extracted } \\
\text { (e.g., study size, PICOS, follow-up period) and provide the citations. }\end{array}$ & Suppl 2 \\
\hline Risk of bias within studies & 19 & $\begin{array}{l}\text { Present data on risk of bias of each study and, if available, any out- } \\
\text { come level assessment (see item 12). }\end{array}$ & 4 and $5^{\star \star *}$ \\
\hline $\begin{array}{l}\text { Results of individual } \\
\text { studies }\end{array}$ & 20 & $\begin{array}{l}\text { For all outcomes considered (benefits or harms), present, for each } \\
\text { study: (a) simple summary data for each intervention group (b) effect } \\
\text { estimates and confidence intervals, ideally with a forest plot. }\end{array}$ & Suppl $2^{*}$ \\
\hline Synthesis of results & 21 & $\begin{array}{l}\text { Present results of each meta-analysis done, including confidence } \\
\text { intervals and measures of consistency. }\end{array}$ & No apply \\
\hline Risk of bias across studies & 22 & $\begin{array}{l}\text { Present results of any assessment of risk of bias across studies (see } \\
\text { Item 15). }\end{array}$ & 0 \\
\hline Additional analysis & 23 & $\begin{array}{l}\text { Give results of additional analyses, if done (e.g., sensitivity or sub- } \\
\text { group analyses, meta-regression [see Item 16]). }\end{array}$ & No apply \\
\hline \multicolumn{4}{|l|}{ DISCUSSION } \\
\hline Summary of evidence & 24 & $\begin{array}{l}\text { Summarize the main findings including the strength of evidence for } \\
\text { each main outcome; consider their relevance to key groups (e.g., } \\
\text { health care providers, users, and policy makers). }\end{array}$ & 5 to 14 \\
\hline Limitations & 25 & $\begin{array}{l}\text { Discuss limitations at study and outcome level (e.g., risk of bias), } \\
\text { and at review-level (e.g., incomplete retrieval of identified research, } \\
\text { reporting bias). }\end{array}$ & 5 \\
\hline Conclusions & 26 & $\begin{array}{l}\text { Provide a general interpretation of the results in the context of other } \\
\text { evidence, and implications for future research. }\end{array}$ & 5 to 14 \\
\hline \multicolumn{4}{|l|}{ FUNDING } \\
\hline Funding & 27 & $\begin{array}{l}\text { Describe sources of funding for the systematic review and other sup- } \\
\text { port (e.g., supply of data); role of funders for the systematic review. }\end{array}$ & 14 \\
\hline
\end{tabular}

Topic 2 and 5: the protocol for this systematic review was no register in any database.

Topic 12, 19, 22: see ***

* We summarize the search strategy using the flowchart proposed by PRISMA (see supplemental material 2). Additional information could be asked to the staff by email to the corresponding author.

** In supplement material 2, PICO strategy for each question is presented.

*** Lack of information to do the correct analysis of an article (e.g.: no clarity control group or measuring parameter), was identified by the reviewers (two for each question), and this was withdrawn if it did not allow to obtain a specific evaluation, however, a standardized evaluation to avoid risk of bias was not used. When a research group or center presented two or more results of an intervention in the same research, we only considered that which included more patients or had a better design. 


\section{Supplementary material 2}

\section{PRISMA flow diagram and PIC strategy}

From: Moher D, Lbeveb A, Tetalsff J, Alt-an DG, The PRISMA Group (2009). Preiemed Reporing lems for Sysiemebic Reviews and

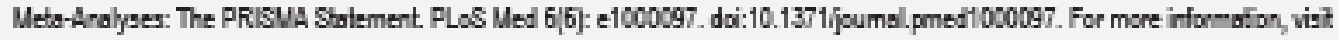
www.pris-g-stabementorg

\section{Question 1. How should we classify atopic dermatitis in clínical practice?}

Participants: alspy den-obifo poíents for any age.

Interventionslexposure: classficabions accoonding phenobype, endobype and genotype

Outcomes: eveluabion of cinical change (pharmacotherapy, severity, prognosic) acconding to classfication.

List and define al variables for which data were sought [eg., PICOS, funding sources] and any assumptions and simplificaions mede.
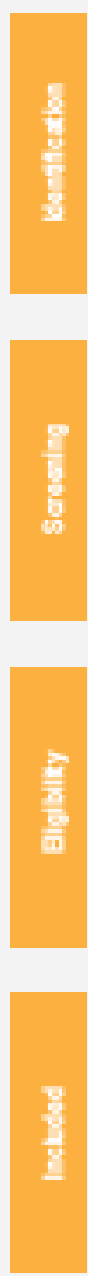
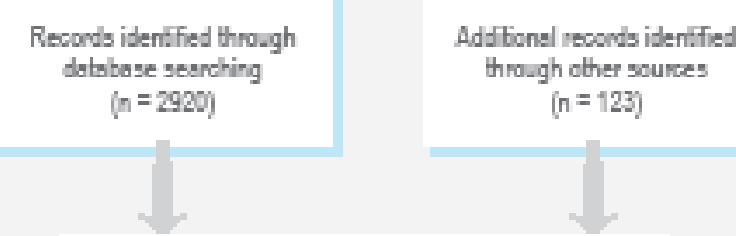

Reconds afier duplcates removed ( $n=2763$ )
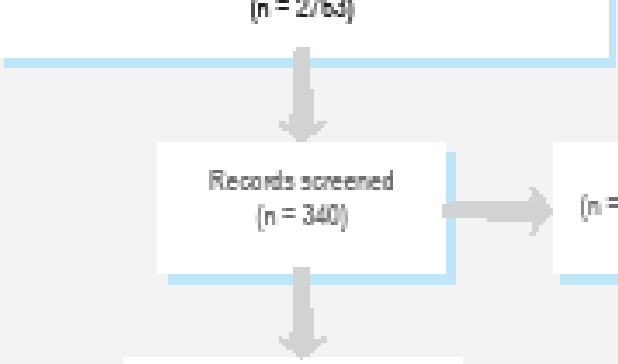

Recorts excluded $(n=2423)$ on basis of the file and absiract.

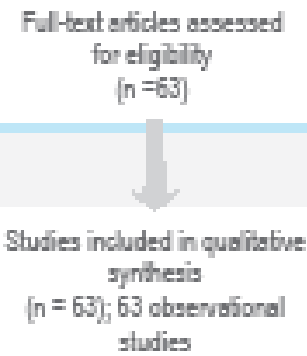

Studies included in qualitabive synthesis

$[n=63)^{2} ; 63$ obsewahoral studies 


\section{Question 2. Can atopic dermatitis be prevented?}

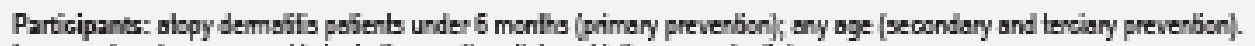

Interventionslexposure: skin hydrajon, mother det, probiobics, neonebe diet

Outcomes: frequency of atopic demstifs, prevention of comaridtes and clnical complicebions.

List and define al variables for which data weve sought (eg., PICOS, funding souxces) and any assumptions and simplificabions mede.
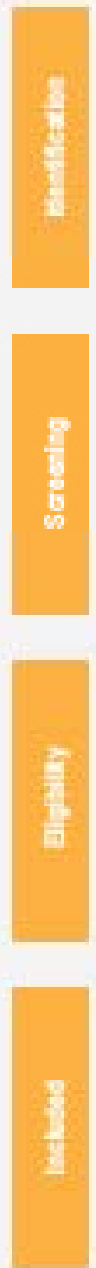
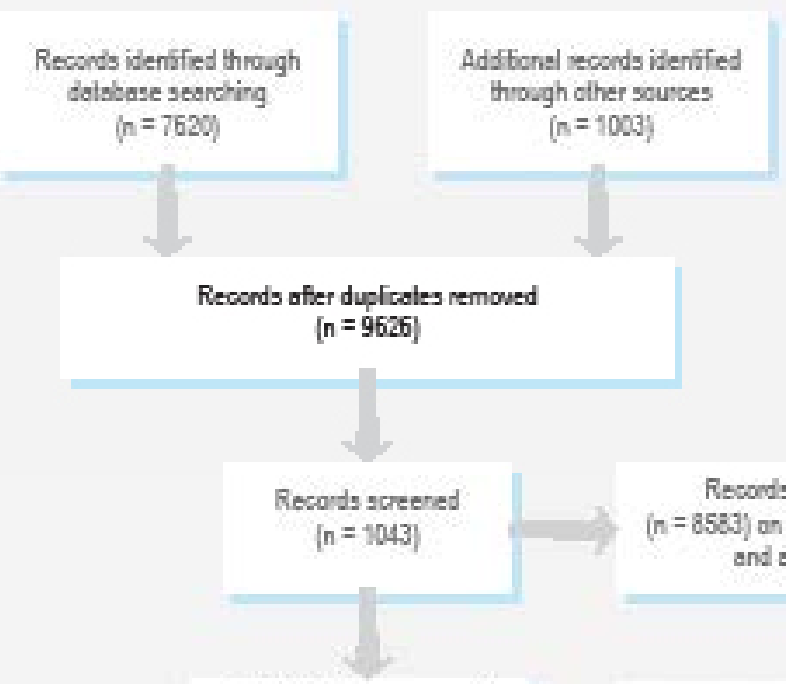

Ful-text erbicles assessed

for eligbilly (n $n=43$ )

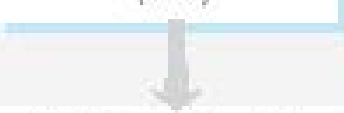

$$
\begin{aligned}
& \text { Recoods exoluded } \\
& \text { ( } n=8583 \text { ) an bosis of the fifle } \\
& \text { and abstred }
\end{aligned}
$$

Shuties inchuded in qualtative synthesis

in $=43 \%, 40$ observational studies, 3 RCTs 


\section{Question 3. Can we predict the duration of atopic dermatitis?}

Participants: aispy demsífs pohients for any sge.

Interventionslexposure: Itenfficabion of risk factors for durafon and severity of abopic derm- oiftos

Outcomes: durafon and seventy of dermatios in fme.

List and deine al veriables for which data weve sought (eg., PICOS, funding souxces) and any assumptions and simplificabions mede.
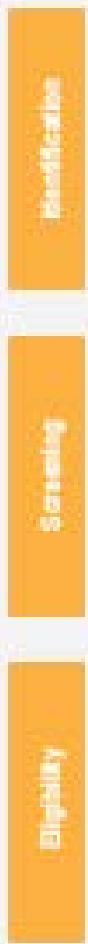

$\frac{3}{8}$
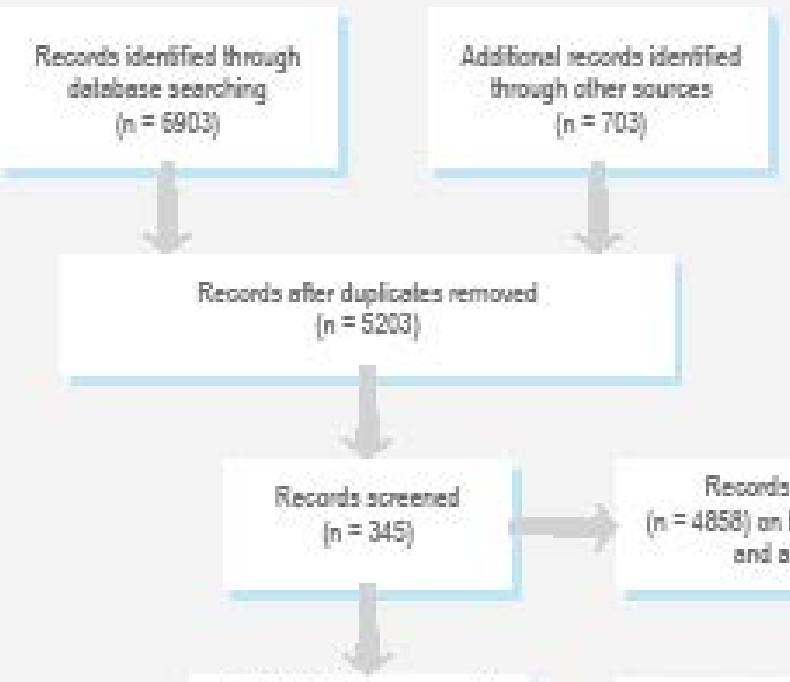

$$
\begin{gathered}
\text { Recoeds exoluded } \\
\text { in }=4858 \text { ) an basis of the tife } \\
\text { and absted }
\end{gathered}
$$

Ful-tert aribies assessed for eligbilly $(n=98)$

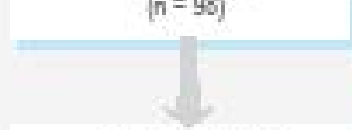
Ful-tent ericles excluded, $[n=247$ ). Ressans: no clear outsame

Shuses inchuded in qualtative synthesis ( $n=98$ ); 98 observational studies 


\section{Question 4. Does the cutaneous microbiota influence the control of atopic dermatitis?}

Participants: aispy demsífs pohients for any sge.

Interventionslexposure: microbioba in skin,

Outcomes: relafionchip with pahogenesis and severity-

List and deine al veriables for which data weve sought (eg., PICOS, funding souxces) and any assumptions and simplificabions mede.
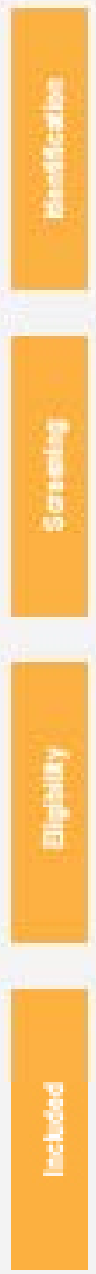
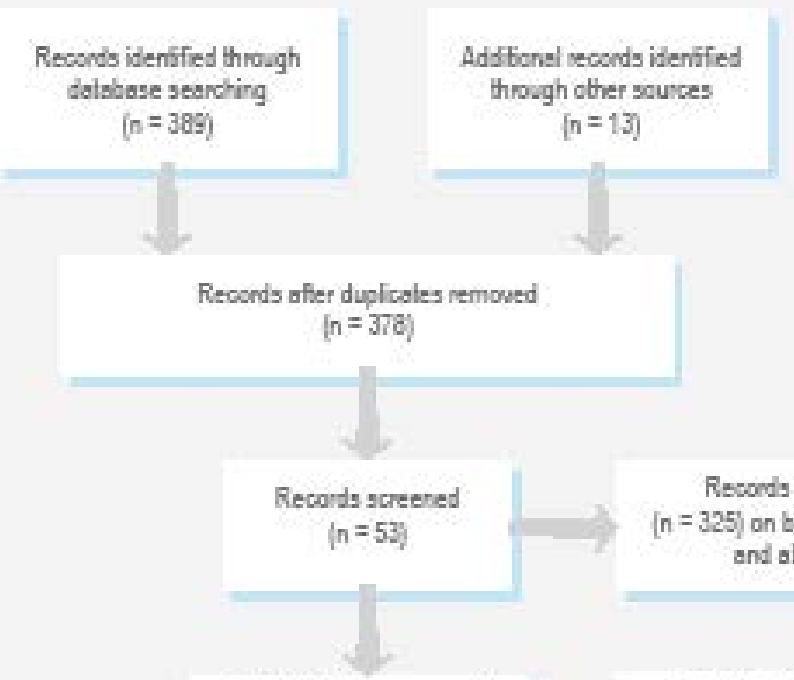

Ful-text aricles assessed

for eligbilly (n=21)

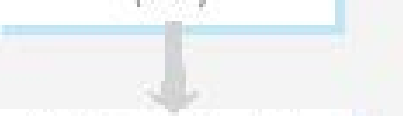

Ful-heat ericles eactuded, (n =32). Reassns: no dear outcome; difterent outrome No full tent 


\section{Question 5 . ls the use of probiotica in atopic dermatitis useful?}

Participants: alspy demsifis poíents for eny sge.

Interventionslexposure: probiotics, prebiofics, symbiotics,

Outcomes: chenges in severity or prevalence of onset.

List and deine al variables for which data weve sought (eg., PICOS, funding sources) and any assumptions and simplficabions mede.
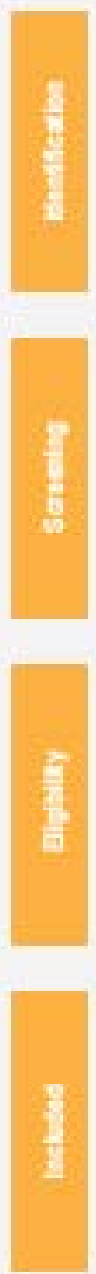
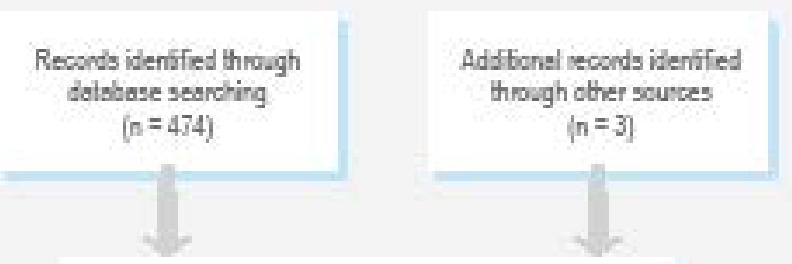

Recosds affer duplcates removed

$$
\text { ( } n=473 \text { ) }
$$
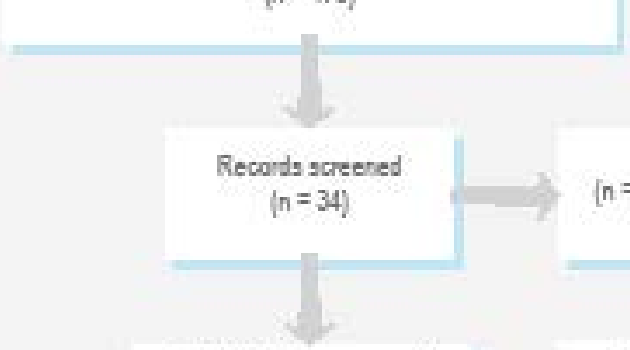

Ful-tert arbices assessed

$$
\text { for efigbilly }
$$$$
\text { ( } n=22 \text { ) }
$$

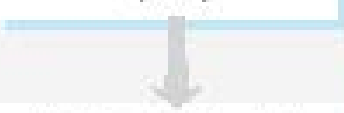

Shuties inchuded in qualìstive synthesis

(n) $=22), 6$ observatonal

shides, and 16 RCTs and

meis-enslysis

\section{Rsconds exoluded \\ ( $n=325$ ) on basis of the tile and abstect \\ Ful-hert siticles encluded, [ $n=32$ ). Ressons: no clear outcome; different outrome No full tent}




\section{Question 6. Can restriction diet help as a treatment of atopic dermatitis?}

Participants: alspy demsifis poíents for any sge.

Interventionslexposure: det restrictions.

Outcomes: clinical charge (pharmacolherapy, severity] sccording to dinical scores.

List and define al veriables for which dala weve sought (eg., PICOS, funding souvces) and any assumptions and simplificabions mede.
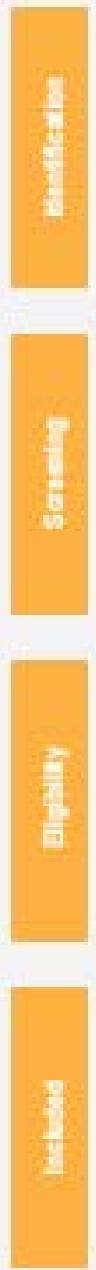
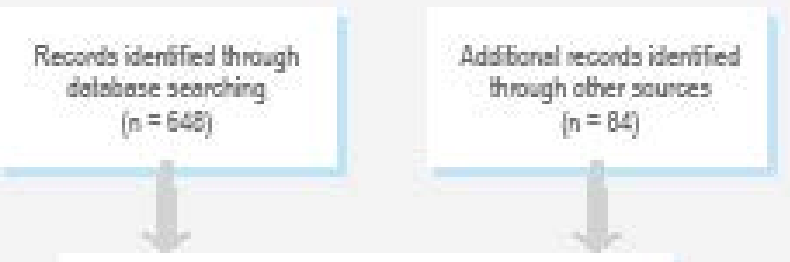

Reconds affer duplcates removed

(n=678)
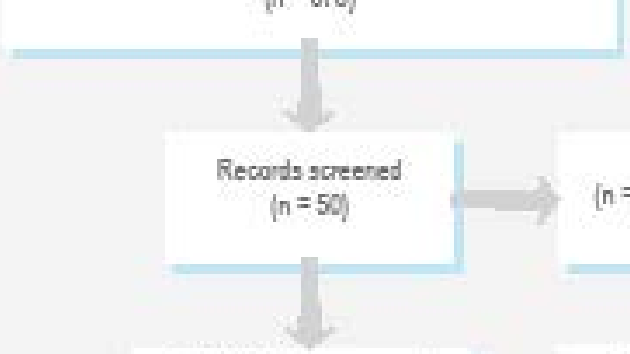

Fultert erbicles assessed

for efigbilly $(n=15)$

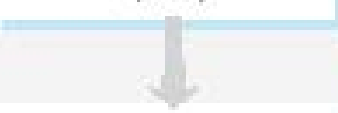

Fithert exicles enduded, $[n=35)$. Reasone: no clear outrome
( $n=628$ ) on basis of the ttle and absivect

Shuties included in quaitative Jynthesis

$(n=15), 15$ obserwajoral stidies 
Question 7. Non-pharmacological interventions are useful in the treatment of dermatitis?

Participants: aispy demsiffs pohents for any soge.

Interventionslexposure: skin hydrofion, clothing, perfumes (avoid)

Outcomes: clinical charge (pharmacolherapy, severity] scoonding to dinical scores.

List and define al veriables for which data were sought (eg., PICOS, funding souxces) and any assumptions and simplifications mede
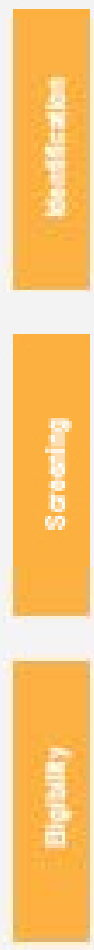

름
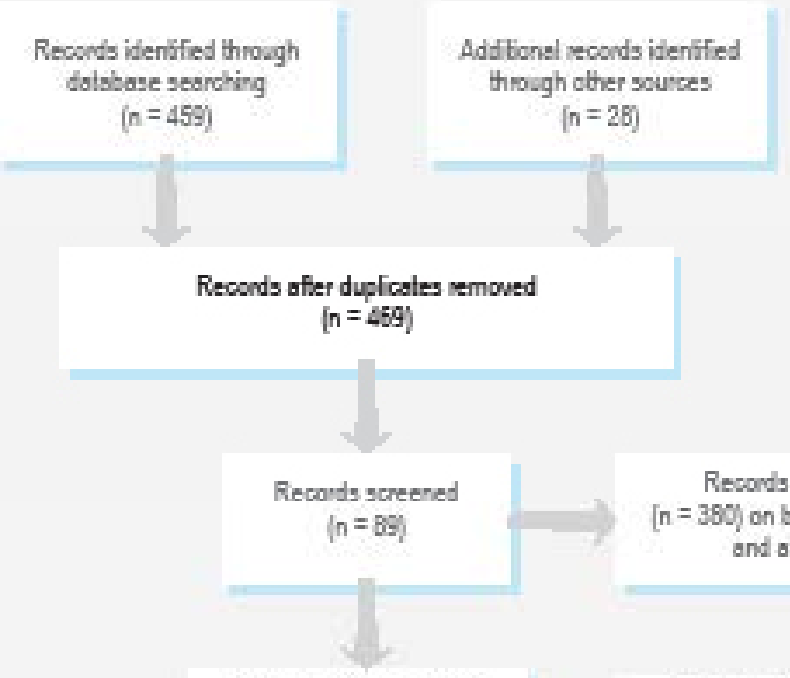

Reconds excluded $[n=390$ ) on basis of the tile and absived

Ful-text arbicles assessed for eligbitly $(n=78)$

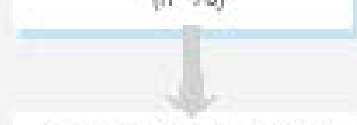

Ful-text aribies eaduled, (n = 11). Reasons: no clea: o.tcome

Studies included in quacitstive synthesis

( $n=78)_{5} 53$ observational studies, and 25 RCTs 


\section{Question 8. Do antihistamines help in the treatment of atopic dermatitis?}

Participants: alspy demsifis pobients for any sge.

Interventionslexposure: anthistamines.

Outcomes: clinical change (phasmacotherapy, seventy] scoonding to dinical scores.

List and deine al variables for which data weve sought (eg., PICOS, funding souxces) and any assumptions and simplificabions mede.
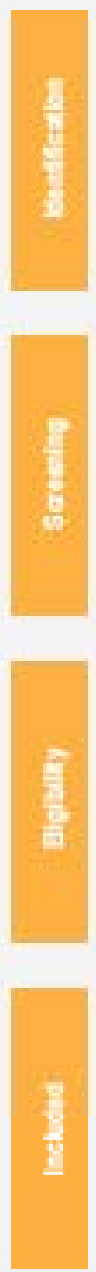
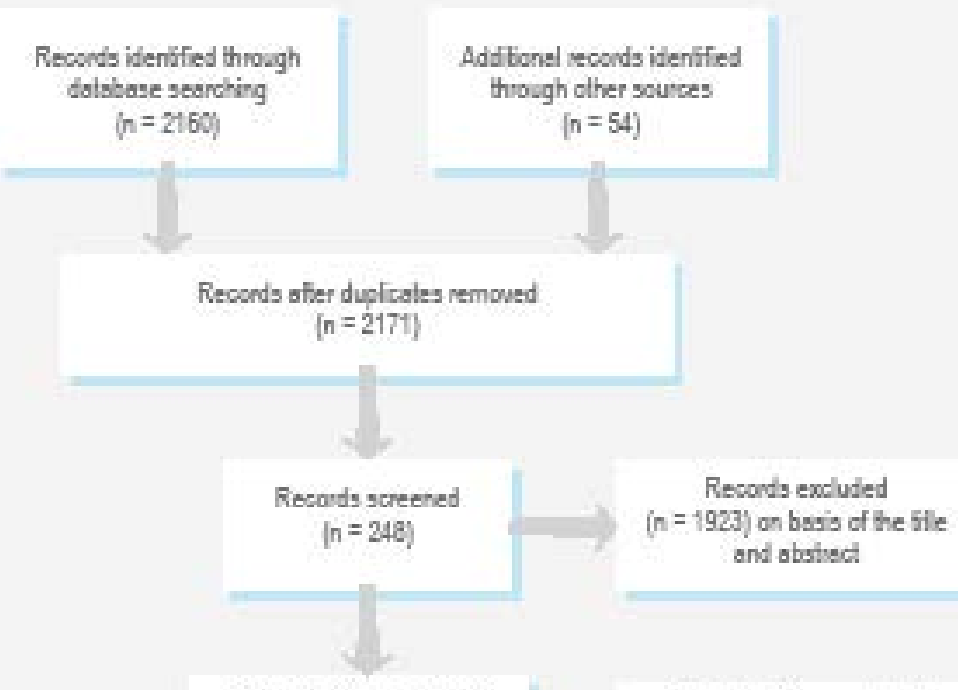

Reconds exoluded in $=1923$ ) on bassis of the file and absivect
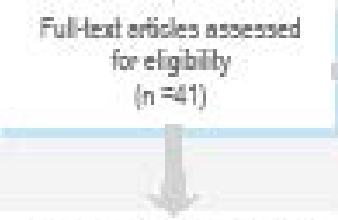
Shuties included in qualitative
sprithesis

( $n=41$ ) 30 obsensaboral

shudies, and 11 RCT.s 


\section{Question 9 . When and what immunomodulator to use in atopic dermatitis?}

Participants: aispy demsiffs poients for any sge.

Interventionslexposure: im-unomodulabors (dupilumbb, phobolherapy, phoischemotheropy, cyclosporine, methobexste, azsithisprine, mycophendate)

Outcomes: clinical change (pharmacolherapy, severity] sccording to dinical scores.

List and define ol veriables for which data weve sought (eg., PICOS, funding souxces) and any assumptions and simplificabions mede.
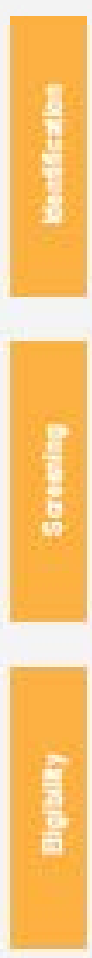

8
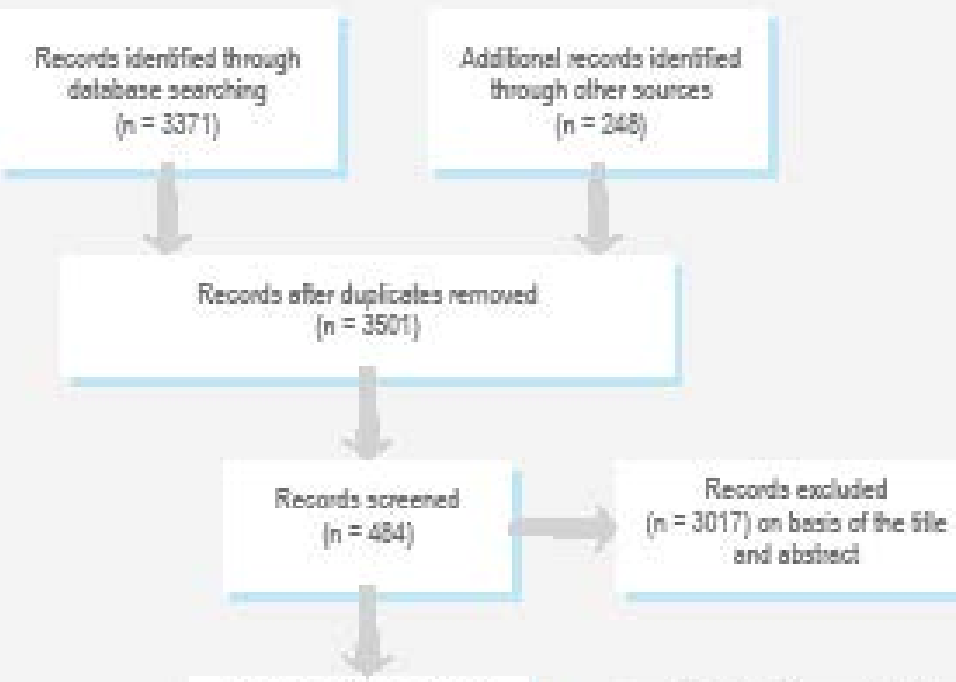

Reconds excluded in = 3017) on bssis of the ille and absivect

\section{Ful-text arbicks asseased} for eligitly $[n=\$ 87)$

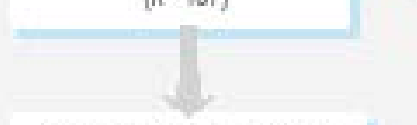

F.l-tert arficies enduded, ( $n=297$ ). Reasons: no clea: outoome

Shuties included in qusirtstue sprithesis ( $n=187)$. 143 observabions studies, and 4 RCTs 


\section{Question 10. What new pharmacological treatmenta are available for atopic dermatitis?}

Participants: aispy demsifis paients for any sge.

Interventionslexposure: Local and sysiemic tialsgical therspies (e.g; crysabonol, d.plumab)

Outcomes: clinical change (pharmacoiherapy, severity] acconding to dinical scores.

List and deine al variables for which data weve sought (eg., PICOS, funding souxces) and any assumptions and simplificabions mede.
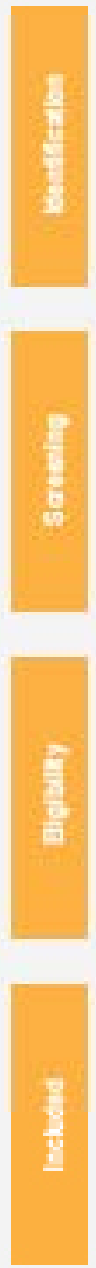
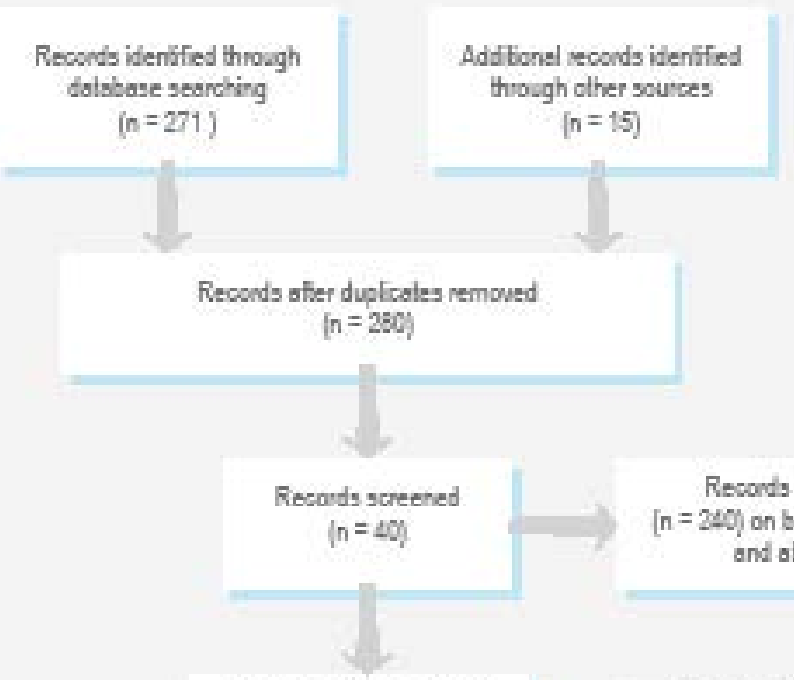
Reconds excluded $[\mathrm{n}=240$ ) on basis of the bile and absivect

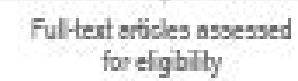
$(n=35)$

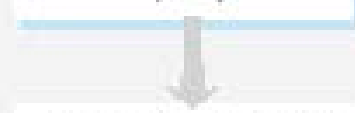

F.l-tent arficies encluded, $\langle n=5$. Reasons: no dear o.toome 